\title{
WHEN I GROW UP
}

A NordjcMagazine about Entrepreneurship Education in Primary and Secondary Schools

PUT PUPILS

IN CHARGE OF THEIR OWN

LEARING

THE GENERAL SECRETARY SAYS

We Will Have to Live off the Next

Generation
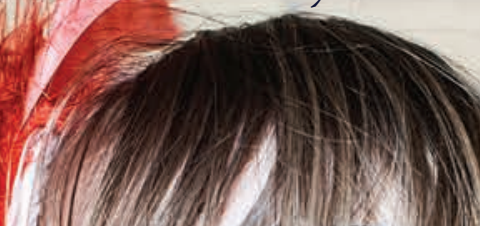



\section{WHEN I GROW UP}

A Nordic Magazine about Entrepreneurship Education in Primary and Secondary Schools 


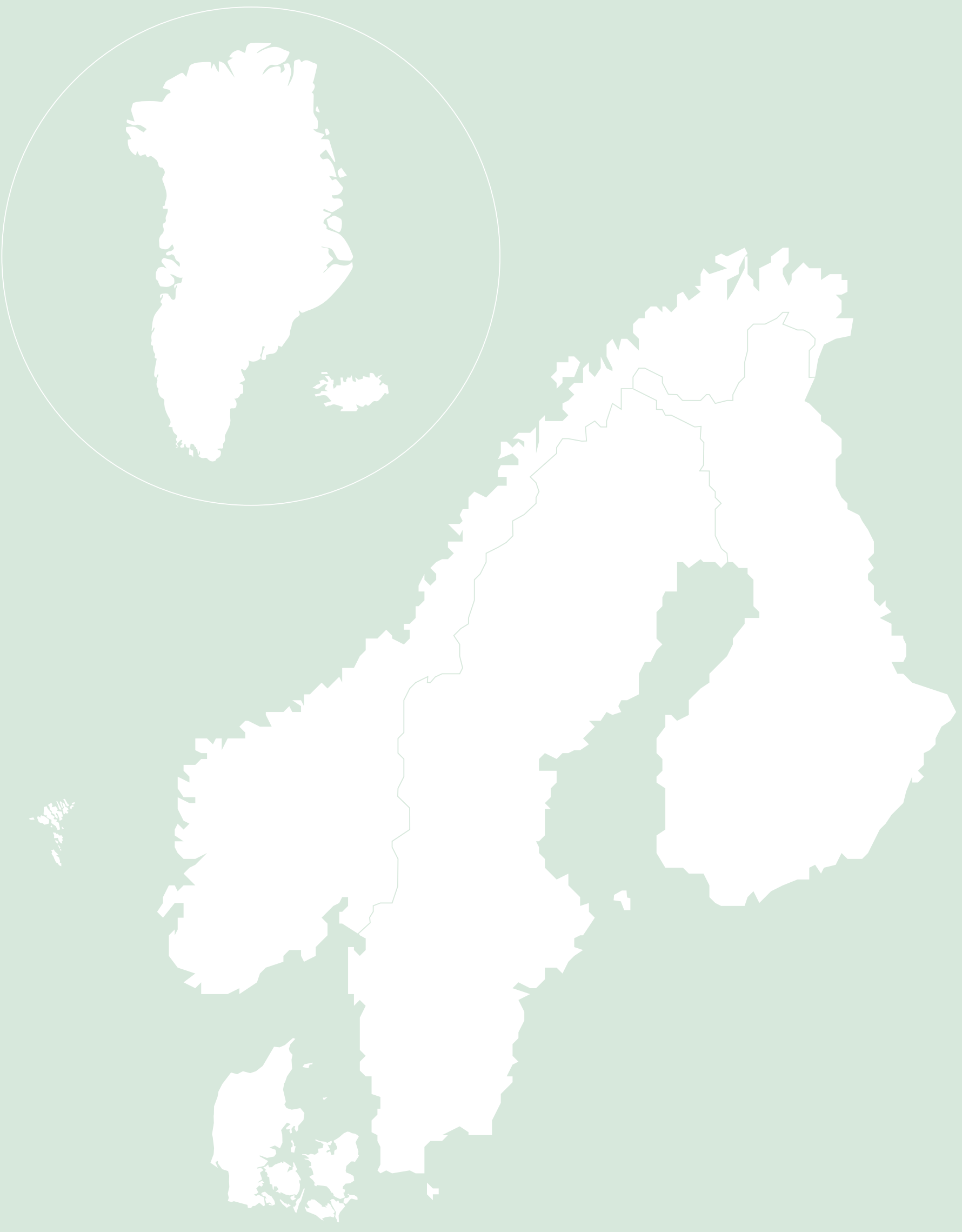




\section{INDEX}

6-7

Freedom of Thought Within a Tight Structure Mellervangskolen

8-9

Nokia - Still Connecting People

Taivalkunta Entrepreneurship School

10-13

No More Classes, Timetables and Lessons

Röselidsskolan

结 $14-15$

Ideas Roam the Hallways

Hofsstadaskóla

16-17

Real Life Produces Magnificent Ideas

Elever af Ellehammer

18-19

Expert: Put Pupils in Charge of Their Own Learning Eva Leffler

20-22

When Natural Science and Music Play Together Biophilia Educational Program

1 24-25

A Day in Society's Engine Room

Yrityskylä

는 $26-27$

Pupils Compete Their Way Through the Tenth Year Íverksetarahúsið
28-29

Courageous From an Early Age

Røsvik skole

1D 30-31

A Taste of the Future

Alléskolan

$42-35$

School from Scratch

Frederiksberg Ny Skole

늠 $\quad 36-37$

Theory Pushing Practice

Løpsmark skole

$+\quad 38-39$

Managing Director at the Age of Ten

Patamäki School

$\stackrel{4}{\Rightarrow} \quad 40-41$

Art in Every Year Group

Ingunnarskóli

42-43

Inventions Move Perceptions

Finn upp

$\rightarrow$ 늘 $\quad 44-45$

On First Name Terms with the Municipality's Technical Supervisor Leikanger ungdomsskule 


\section{READING GUIDE}

What can you read about in this magazine?

The magazine contains 16 different cases that describe what kind of work is currently undertaken in relation to entrepreneurship education in Nordic primary and secondary schools. The examples constitute short, easily readable articles that describe parts of the entrepreneurial practice in a specific school or within a certain area in the Nordic Region.

How did we decide on which cases to include?

The different cases were chosen by way of an explorative process in which a number of key people within the educational field in the Nordic Region have been asked to point to good and inspiring examples of how entrepreneurship is taught in primary and secondary schools, after which relevant experts were approached and asked to do the same.

This process resulted a lot more good cases than we were able to include in the magazine, and thus the cases presented here were chosen according to the following criteria:

\section{Projects or activities, which}

* Are consciously related to entrepreneurship education or innovation by the people working with them

* Have been implemented for long enough to produce experiences and results

* Represent a geographical spread across the Nordic Region.

The cases therefore should be read as good examples, not necessarily best practice.

How is entrepreneurship defined in the magazine?

The articles have been written with the understanding that there is no absolute definition of entrepreneurship in an educational context. Each article thus defines entrepreneurship in accordance with how the people interviewed understand the term. The magazine contains examples of highly visible entrepreneurship in the shape of concrete, timebound activities as well as what may offhand appear as more invisible entrepreneurship in the shape of different pedagogical approaches that are integrated in and across activities.

\section{Who wrote the articles?}

The Nordic Council of Ministers asked the Scandinavian think tank Monday Morning to be in charge of the publication, which is also why Monday Morning is editorially responsible for the magazine. 


\section{WE WILL HAVE TO LIVE OFF THE NEXT GENERATION}

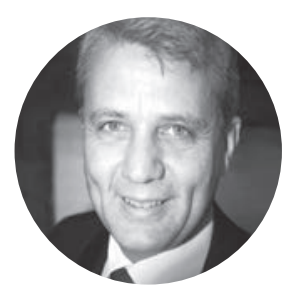

Within the past few years, the Nordic welfare model has been getting rather a lot of international attention. The ability to combine economic growth and dynamism with generous and tax-funded welfare has shown its strength during the economic crisis. However, the Nordic welfare systems are under pressure. Globalisation, financial crisis, demographic changes and new technology all challenge the countries' possibilities for maintaining and developing the welfare state.

Although there are many thoughts on what will sustain future populations in the Nordic Region, one thing is certain: we will have to live off the next generation. It is becoming increasingly clear that we shall have to live off our own - and our children's - ability to come up with new ideas, to locate potential and to turn ideas into action. Within all sectors and all professions, competences and drive are called for if we are to cross that bridge, and this in turn places new demands on education at every level. Entrepreneurship education must be developed and integrated by way of subjects and courses, but also by applying new pedagogical and didactic approaches to existing teaching.

This is also why it is important and greatly cherished when accomplished teachers and headmasters/ -mistresses at Nordic primary and secondary schools incorporate new pedagogical tools in current teaching and start collaborations with businesses and other actors you would not previously have expected to encounter in a school yard. Fortunately, this is often the case.

In 2012, Nordic Innovation, under the Nordic Council of Ministers, carried out an analysis, which pointed to the fact that the training and motivation of teachers in relation to entrepreneurship education was lacking behind the Nordic countries' political visions in this area. The aim of this magazine is to encourage and inspire teachers and headmasters/-mistresses at Nordic schools to acquire their own experiences with entrepreneurship education. I have personally met several youngsters who within the last few years have been afforded the opportunity of trying their hand at innovative entrepreneurship within a school framework, and there is no doubt that these opportunities release a great deal of creative power in young people.

In this magazine, you will find numerous examples of how different people in the Nordic Region work with entrepreneurship education as well as their results so far, such as the pupils at Dansborgskolen in Hvidovre, Denmark, who develop solutions to concrete challenges in collaboration with the local hospital and the local centre for wastewater. Or pupils from Yrityskylä in Finland who for a time manage to turn a gym into an urban society. Or when a group of boys from Alléskolan in Åtvidaberg, Sweden, visit local businesses for inspiration and motivation. All of this enhances the pupils' ability to think in new ways and to come up with solutions.

Finding new solutions to sustaining future welfare is also the aim of the Nordic Council of Ministers' program Sustainable Nordic Welfare, which this publication is part of. Most often, new solutions arise when existing frameworks and structures are challenged. And so it is my wish that this publication will contribute to even more headmasters-/mistresses and teachers daring to challenge their current point of departure by bringing subject knowledge and pedagogy into play in new ways.

Enjoy the read!

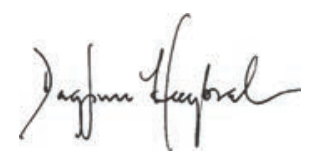

Dagfinn Høybråten,

Secretary General, Nordic Council of Ministers 


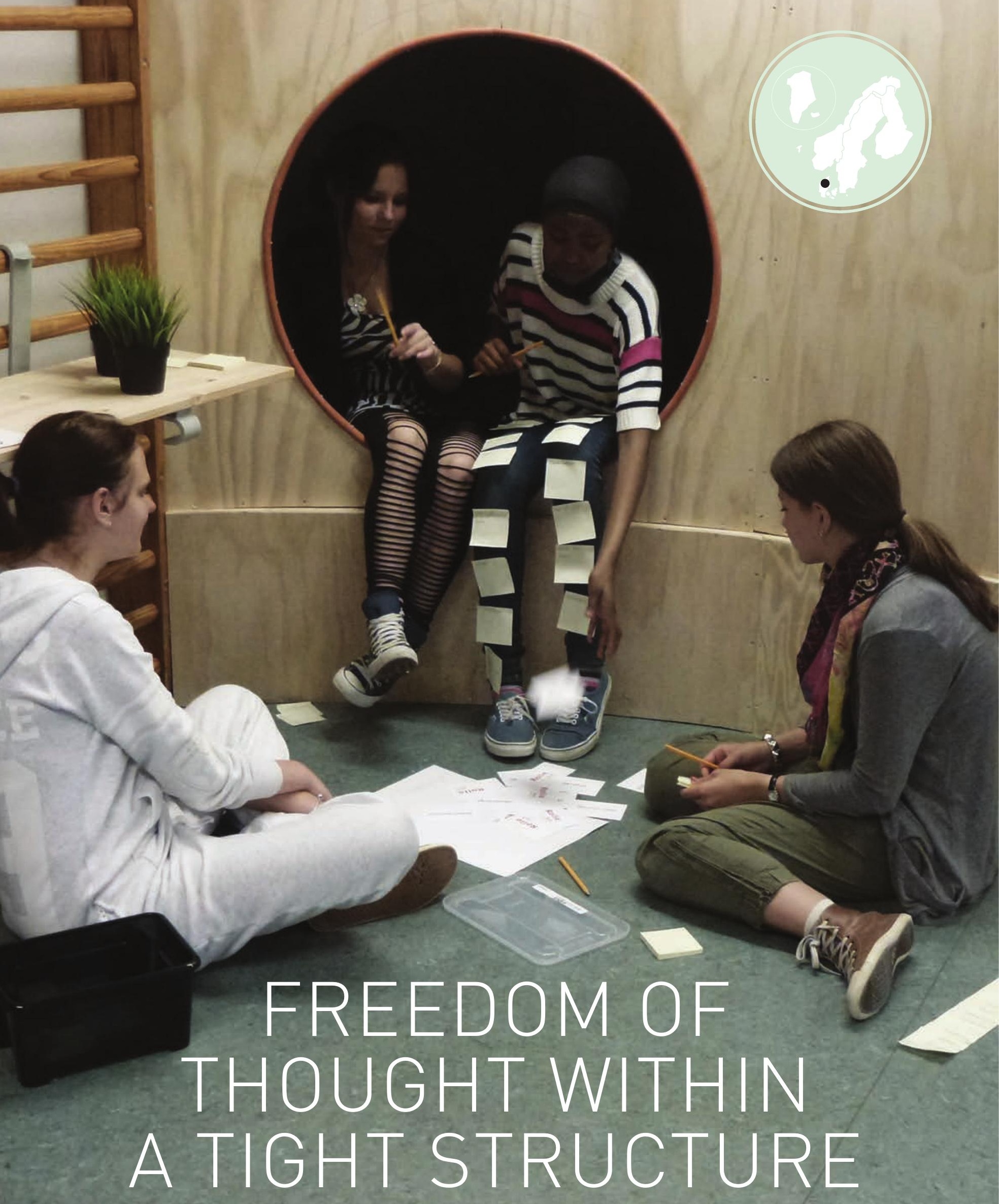


At Mellervangskolen in Aalborg, Denmark, uneven angles, colourful rubber bands and real mistakes are all part of everyday life. They have established The Lopsided Room, where pupils and teachers practise how to locate potential and find courage.

A huge chandelier in the middle of the room sheds light on a curved bench and two trees planted right in the middle of the floor. The windows have shutters, which function both as blinds and as blackboards where you can draw an idea if you are not yet familiar with the alphabet.

In The Lopsided Room at Mellervangskolen, nothing is as you would expect in a normal classroom. It is a special-subjectroom and a thought-exploratorium rolled into one. All pupils come here on a regular basis, spending entire days - camps working on for example maths or Danish in new ways. At other times, they may engage with concrete problems from their own everyday life or problems that spring from the local community.

\section{A NEW AND BRAVE SCHOOL}

The decision to create a 'lopsided' room was reached following a prolonged period in which the school had engaged in smaller attempts at bringing creativity, innovation and entrepreneurship more into play within the school. According to teacher Carsten Hermansen, who together with his colleague Charlotte Rørvig Haaber constitute the resident teachers in The Lopsided Room, the room does away with the idea of the traditional classroom and the limitations it entails. 'A school is actually a rather conservative construction; it both looks and behaves in a very specific way. We would like to create a new kind of school where pupils to a much greater degree see the point of what they are doing, and where they dare actively participate in the learning process and come up with ideas. This room allows us to utilize the pupils' time and resources much better than we have traditionally done', he explains.

\section{REDUCING WASTED TIME}

Time is central to The Lopsided Room. Traditional 45-minute modules have been abolished and replaced by an entire day spent solving a number of smaller group projects that can be as short as a couple of minutes each. Different coloured rubber bands are handed out to all pupils at the beginning of the day as this enables the teacher to control the group work by deciding, by way of example, when pupils wearing yellow rubber bands must share their ideas with everyone else. This way they avoid wasting time on pupils trying to build up courage or on deciding who does what. According to Carsten Hermansen, a prerequisite for allowing the pupils to work creatively in a space where their ideas can soar is exactly stringent control.

\section{'This room allows us to utilize the pupils' time and resources much better than we have traditionally done'.}

Carsten Hermansen, teacher

'The most important thing is to let the children's rather than the adults' thoughts and ideas come into play. So if you want them to work with specific subject concepts, you have to provide the framework within which they can work on these ideas. And this way, we make them think about specific subjects but in their own way', he states.

\section{HURRAY, I'VE MADE A MISTAKE!}

As pupils work with assignments and on developing ideas, there is only one strictly forbidden word, and that is 'no'.
In The Lopsided Room, you have to say, 'yes and then what?' This rule is supposed to empower the pupils to see possibilities and find new solutions when they come up against something they find difficult. And at the same time, they are practicing how making mistakes can be a good thing. Because it is actually only by trying and failing mistakes that you really learn something, Carsten Hermansen explains.

The Lopsided Room allows for plenty of mistakes to see the light of day. Several times throughout the day, pupils present their ideas and results to the other pupils. They have to step through an old wooden door, placed at the centre of the room, and out in front of their classmates. It is an exercise that forces them to be a little braver than they thought they were.

And according to Carsten Hermansen, making children brave is what The Lopsided Room is all about, 'To me, it's all about shaping pupils who believe that once they put their mind to something, they can succeed. It's about providing children with skills and methods that will enable them to live good lives in a changing world. And we believe that working like this will enable them to do just that'.

\section{DO-IT-YOURSELF}

The Lopsided Room has its own blog (in Danish) where you can find out more about how the pupils at Mellervangskolen work in camps on an everyday basis. You will also find inspiration in relation to including energizers or props in your teaching.

You find the blog here: http://innospot.skoleblogs.dk/ 

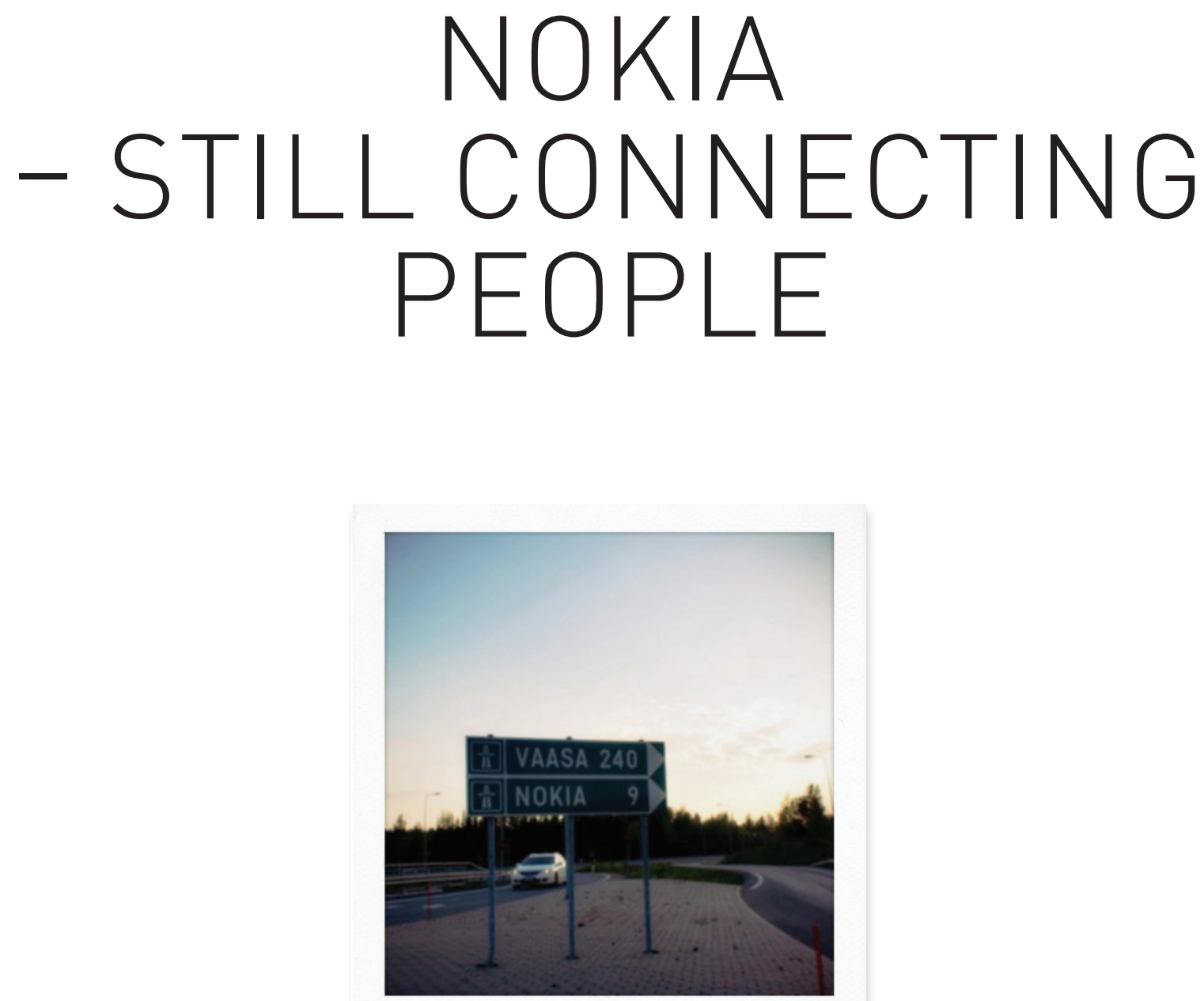

The prospect of a school closure and sensing that the pupils' self-esteem needed a boost made the headmaster of the little school Taivalkunta in the town of Nokia in Finland resort to unorthodox measures as he opened up the school to the outside world. 


\section{'I believe that many people fear that thinking about schools in a new way entails a lot of extra work, and teachers are already working really hard. But I gain more than I lose from working like this'.}

Kari Haikonen, headmaster

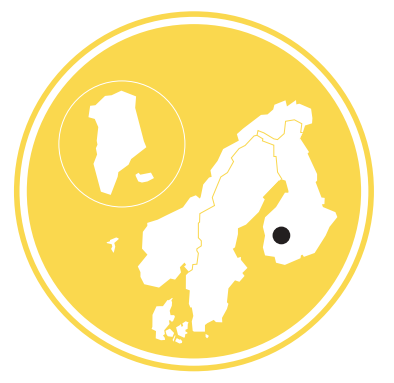

invited in. One of Kari Haikonen's ideas was having the pupils aged 10-12 organize a stand at Nokia's yearly business fair, Nokia Messut, where the town's businesses would present their work to the general public. The fair agreed and so the pupils - the only children there - arranged a stand with birdhouses they themselves had made.

And it turned into a great success. During the fair, which lasted a weekend, the pupils managed to sell all of their 100 birdhouses, their stand was awarded best stand at the fair, and Nokia's mayor gave a speech at the pupils' stand, encouraging them to engage in similar initiatives more often. 'It may not sound like much, but it was huge for a 10-12-year-old', Kari Haikonen comments on the commotion that surrounded the pupils' stand. 'On the first day, the pupils were frightened to talk to people, but within two days, their courage rose greatly and they would even leave the stand to present their products to people they didn't know'.

$\mathrm{He}$ also found that the pupils' level of concentration once they were back in the classroom had greatly improved, 'Suddenly it was much easier to get them to focus. I believe that it was simply a motivating experience for them'.

\section{STAND AT A FAIR FOR ADULTS}

Kari Haikonen noticed that pupils attending the school lacked the courage to step up and voice their opinions. And this was not just in class. They were often quiet and difficult to engage, and so he decided to open up the school: the pupils would have to venture out of the school and the outside world would be own initiative and they were more attentive during visits than they normally were - even as senior executives stressed the importance of learning maths and languages. The visits back and forth numbered 14 in one year, and Kari Haikonen's reflects on them thus, 'Here's a person who has made the effort to come and see US. Someone with their own business and employees, and when they explain that maths is important, pupils tend to pay more attention than when I say so'.

\section{IT WAS HARD BUT WORTH IT}

As it turned out, Taivalkunta Entrepreneurship School, which is the name of the school today, was not closed down, but Kari Haikonen who is now 60 years old, sometimes worry what will happen to the school once he is no longer around. He hopes that his successor(s) will continue some of the initiatives in their own way. But he has received no feedback from the organisations and universities that he contacted to try and spread the advantages of an entrepreneurial approach to teaching. 'I believe that many people fear that thinking about schools in a new way entails a lot of extra work, and teachers are already working really hard. But I gain more than I lose from working like this. It takes a lot of effort, but you get even more in return. I have become stronger, more motivated and eager to try more new things and be productive'.

It may well be that the phone company Nokia upped and left, but their worldrenowned slogan, 'connecting people' is still valid around this town. 


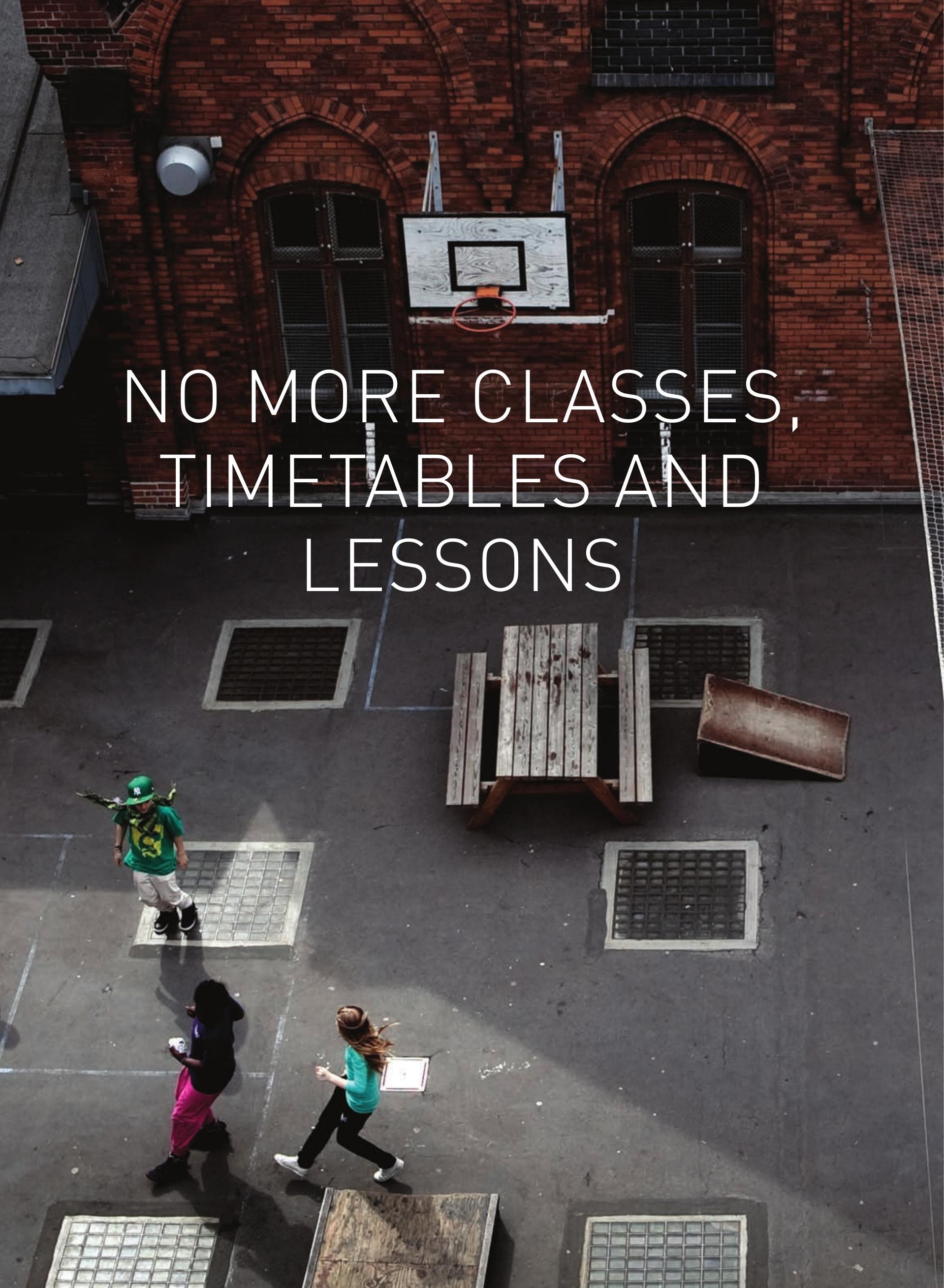


At Röselidsskolan north of Gothenburg, an entrepreneurially focused pedagogy permeates all the school's work. Only one third of all teaching is timetabled - and pupils are actively engaged in planning the remainder of the time.

I $\mathrm{t}$ was a deliberately set fire in 2007 that burned a school in the district of Gråbo in Lerum Municipality to the ground. However, the fire afforded the town an opportunity to rebuild not just a physical framework but also the pedagogical foundation. The aim was uprooting the social problems that had long been setting the agenda in this little community north of Gothenburg - and the lever was three new schools.

'We were experiencing big problems with crime and conflicts among the young and so there was a great wish to change course. The key words to change were safety and social durability by focusing on entrepreneurship', Lennart Nilsson, headmaster at one of the three new schools in Gråbo, Röseliddskolan, explains. 'An entrepreneur is someone who generates increased value and our aim to teach our pupils how to constantly think in terms to generate increasing value for someone', Lennart Nilsson elaborates.

\section{DAILY STOCKTAKING}

At Rösalidsskolan they actively strive to avoid using words such as class, timetable and lesson. Instead, the pupils are divided into work-communities of 60-90 pupils where they collaborate across year groups. In addition, they are also part of a process-group of approx. $15 \mathrm{pu}$ pils who constitute the daily point of reference. Only one third of all teaching is timetabled.

Each morning the pupils meet with their process-group and their teacher to take stock of and set goals for the day. For example, the pupils did a project on great inventions, covering subjects such as history, natural sciences and Swedish. 'In their process-group they would look at how each individual pupil could approach the assignment. Some pupils would like to write, others would like to take photographs. They all share the same overall learning target, but it is important to emphasise that there are different ways of reaching this target, and each individual pupil must take part in deciding what is right for them', Lennart Nilsson states. 


\title{
'They all share the same overall learning target, but it's important to emphasise that there are different ways of reaching this target, and each individual pupil must take part in deciding what is right for them'.
}

\author{
Lennart Nilsson, headmaster
}

In his experience, some of the pupils are good at planning time over longer periods, while others need daily intermediate goals, which will enable them to decide which part of the assignment to attack first.

\section{A NEW ROLE FOR THE TEACHER}

As part of the restructuring, the teachers at Gråbo's newly built schools work in regular teams, and this among other things, means spending more hours at the school than previously. 'The teachers have been used to planning their own teaching and their own time, however, today, they need to be present at the school to a much greater degree, and they need to continuously work together', Lennart Nilsson explains. In order to strengthen the teachers in this new approach, each team has a weekly meeting where they discuss the plan for the following week. 'Working together like this is new for the teachers, and we have talked about it a lot. Everybody had to re-apply for their job, so everybody accepts that this is the way we do things now', Lennart Nilsson elaborates. Two thirds of the school's teachers were previously employed at the schools in Gråbo, while the remaining third are new teachers.

\section{TEACHING ON FACEBOOK}

A substantial part of their work consists of coaching the pupils, who often work with projects lasting typically 2-3 weeks. As they go along, the teacher will assist the pupils in moving forward by asking questions such as: Where in the process are you? What works well for you? What can you do better? How do you plan to continue?

To exemplify a project, Lennar Nilsson explains about an eighth year group at Röselidsskolan who had to conduct a virtual journey through Europe.
Each pupil was 'given' EUR 50,000 and then had to make their own way across. The teachers would constantly bring in concrete assignments that needed solving as they crossed the continent, such as 'you need a new passport' or 'write a CV in English so you can apply for a job'. The project had its own Facebook page and all communication was conducted on the social network. The pupils became so caught up in it that they would spend time on Facebook both in the mornings and in the evenings in order to continue their journey. The project was inspired by storyline and case pedagogy and according to Lennart Nilsson, it was a success because it utilized a media with which the pupils were already familiar.

\section{THE SCHOOLS IN}

\section{GRÅBO}

* Three new schools have been built in Gråbo, Ljungviksskolan, Lekstorpsskolan and Röselidsskolan. Each school has specialised in particular subjects. At Röselidsskolan, which opened in 2012, it is sports, home science and languages, while the other schools offer natural science subjects and music and drama, respectively.

* From the fourth year, pupils can use the subject classrooms at the two other schools, and in years eighth to nine, they spend entire periods at the other schools.

* The pupils themselves were involved in choosing which of the three schools they would be signed up at after the refurbishing. 
The pupils at Röselidsskolan are not divided into classes but rather bigger groups called work-communities and smaller groups of approx. 15 pupils called process-groups. Each morning the pupils meet up with the process-group and their teacher and set goals for the day.

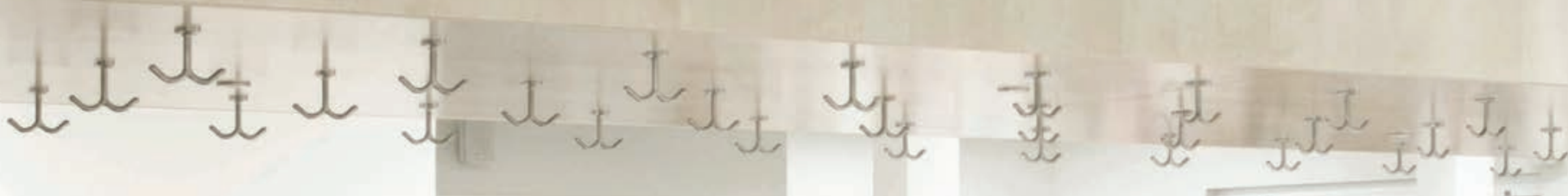

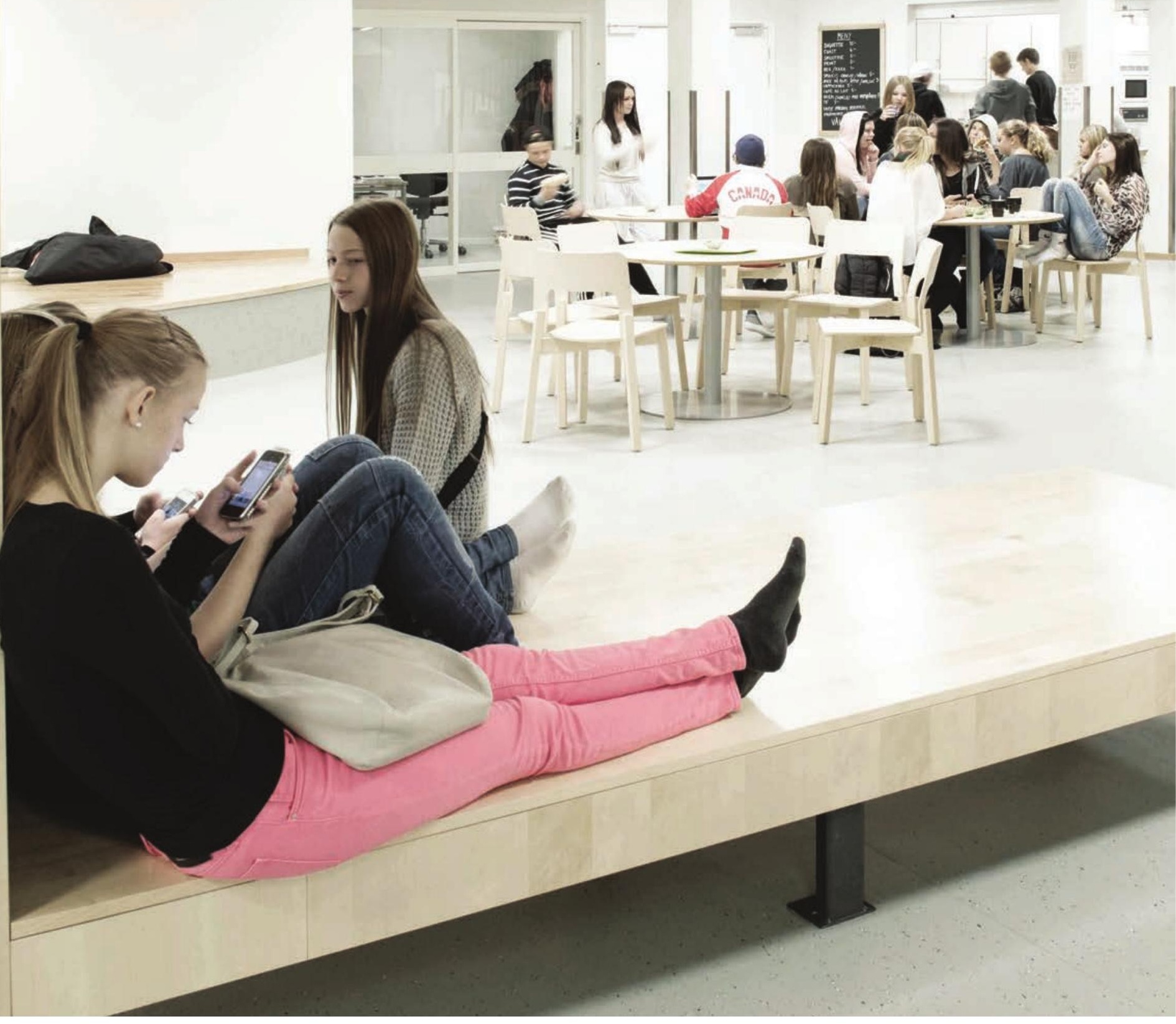



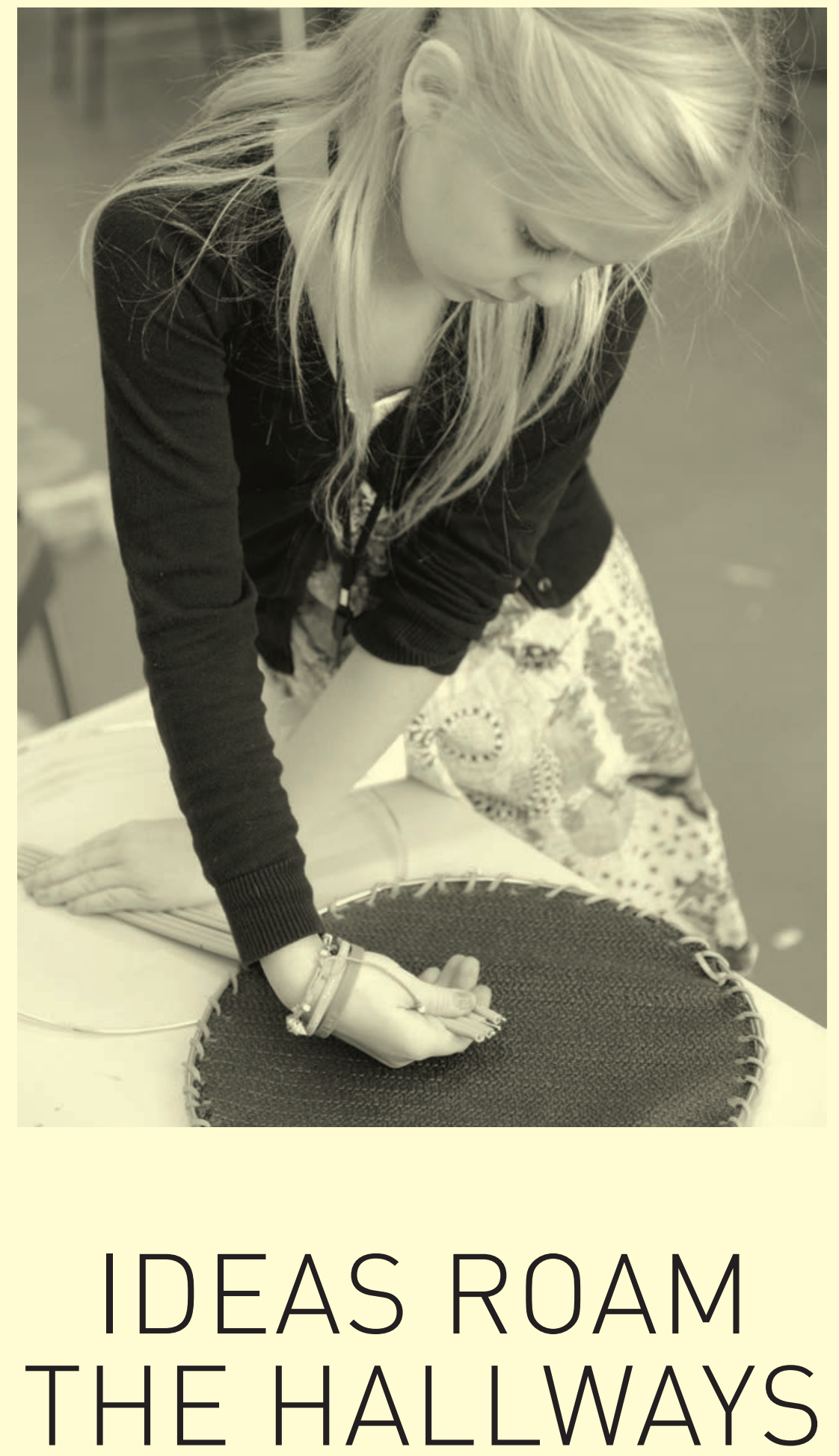

A good idea can help change society and shape your future. These are two key messages communicated to the pupils at the Icelandic school Hofsstadaskóla - a school where, for the last nine years, innovation and idea generation have been part of the curriculum from the fifth year onwards. 


\section{'Pupils often stop me in the hallway to tell me that they came up with a great idea during the summer holidays or over the weekend. Coming up with new ideas and then developing them has become a way of life for them'.}

\author{
Sædís Arndal, teacher
}

S ome pupils quickly pick up on how to read and write, while others finish their fractions ahead of everyone else. And some pupils are always the first to be picked for any team in PE lessons, because they are great at sports.

However, reading, maths and sports are not the only disciplines you can excel at. Within the last nine years, the Icelandic school Hofsstadarskóla has called attention to and encouraged the importance of coming up with a good idea. The school includes years 1-7, and the older pupils are taught innovation and idea generation.

\section{AS GOOD AS THE ADULTS}

In the fifth year, pupils have one innovation lesson a week for five to six weeks, where they discuss what innovation is and what constitutes a good idea as well as how to realize this good idea and create value. 'Which problem has this idea solved?' is one of the central questions with which pupils engage.

They are then asked to locate problems and solutions within their local community, and everybody is given a small notebook in which they can jot down their ideas as soon as they come up. Back in the classroom, they continue to develop their ideas, which includes presenting them to their classmates, making posters and building prototypes. At the end of the school year, all pupils in the fifth year take part in an internal school competition where the best ideas are awarded a first, second and third prize.

Once the pupils start in the sixth or seventh year, even greater emphasis is placed on pupils learning how to convert ideas into projects. In the sixth year, in woodwork classes for example, they will be asked to make a lamp out of things that have been stowed away in lofts or basements at home. One of the challenges could be finding a way of hiding the cord. A senior design lecturer from the technical school in the neighbouring municipality will then decide on the best solution for design as well as on which lamp includes the best way of hiding the cord.

The recognition of creative competences is highly useful as it appeals to a wide range of pupils, says Hafdis B. Kristmundsdóttir, deputy head of the school. It is particularly important to note its strong appeal to some of the pupils who are usually more quiet and reserved in the academic subjects. 'They show new sides of themselves and you can see their selfesteem rising' Hafdis B. Kristmundsdóttir explains before elaborating on the broader perspectives of the initiative, 'It's a way of educating the children. We want to make them trust that their ideas are as good as the adults' and that they do not have to perform equally well in the same subjects'.

\section{A NEW SCHOOL CULTURE}

That good ideas are in season all year round for the pupils at Hofsstadaskóla has also been noted outside the school property. The school is without competition when it comes to the number of entries sent to the national competition for entrepreneurship for the 10-12-year-olds organized by the NKG (Nýsköpunarkeppni grunnskólanemenda).

The explanation lies in the fact that idea generation and innovation are no longer subjects that are confined to only a set amount of lessons each week. 'It has become part of the school culture and is reflected in the way the pupils perform both in and outside lessons. Pupils often stop me in the hallway to tell me that they came up with a great idea during the summer holidays or over the weekend. Coming up with new ideas and then developing them has become a way of life for

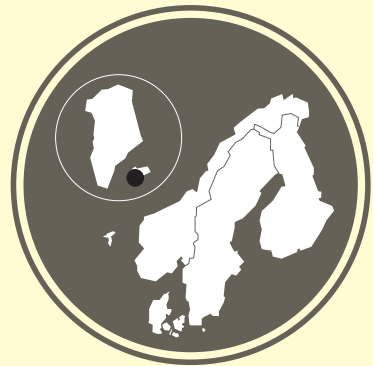

them', Sædís Arndal, a woodworks teacher who also teaches innovation in addition to organising the pupils' participation in the school competition, explains.

Sædís Arndal continues that once, she even sold one of the pupils' ideas - a butter knife that could be included in the packaging - to a company that packages and sells cold cuts to show the pupils that it is possible to patent a good idea and make money that way.

\section{HAVING LEARNT TO LISTEN TO THE PUPILS}

'I imagine that many people believe that good ideas pop out of a black box - that it cannot be learned in the same way that maths and sports can. However, our experiences reveal the exact opposite. Idea generation is something that can be practiced and anybody and everybody can come up with a good and useful idea. For some, it may take a little longer, and for even fewer, it may take a very long time, but we can see how they get better and better at it - all they need is practice', Sædís Arndal says. She continues by explaining, 'It's mostly about motivating the pupils to believe in their own ideas - especially at the outset. They need to experience that making an effort and working hard actually makes a difference. Which is also why the concept of a bad idea simply does not exist. All ideas are good ideas'.

But have we not always paid heed to children's ideas, one is tempted to ask? 'No. Previously, not much attention was paid to the ideas and opinions of children and young people. This has gradually changed and I consider that a change for the better. Society also shows us that design, innovation, entrepreneurship and creativity are becoming evermore important, and so we have to keep up with that development as well', says Hafdis B. Kristmundsdóttir. 

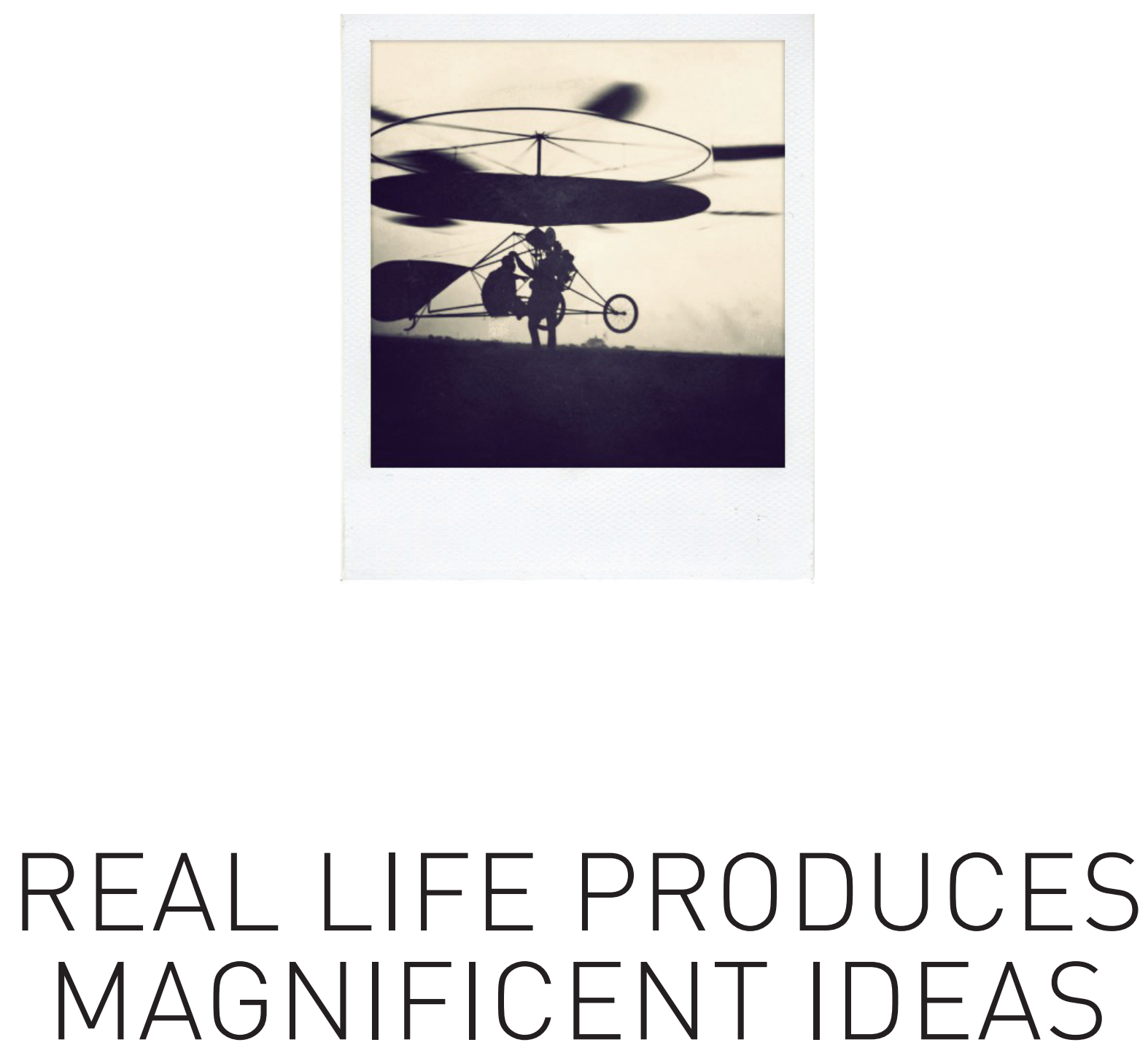

At Dansborgskolen in Hvidovre, southwest of Copenhagen, they have substituted the traditional project assignment in the ninth year with business-oriented problem solving, resulting in highly driven pupils and teachers with new responsibilities. 


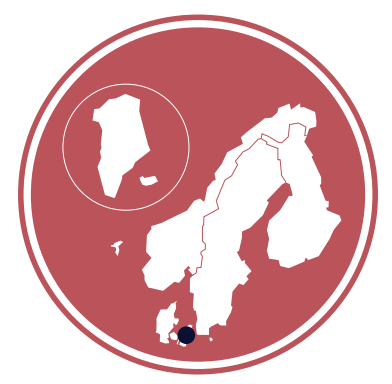

$\mathrm{T}$ ime and again, teacher Christian Black-Storm watched his pupils in the ninth year writing project assignments that were either attempts at 'saving the entire globe' or about subjects they simply could not relate to. 'They would all write about anorexia or homelessness. But these are problems that are so far from their everyday lives that it simply becomes too abstract. For a long time, I've tried to locate some sort of medication for this alienation we often encounter when teaching', he explains.

Christian Black-Storm wants to give pupils something they can actually see and feel the purpose of doing. And so, only last year, he took the plunge and in collaboration with fellow teachers, he substituted the traditional project assignment for pupils in the ninth year with projects connected to an initiative called 'Elever af Ellehammer' (Students of Ellehammer).

\section{SOLAR CELLS, WASTEWATER AND A FRIENDLY WAITING ROOM}

'Elever af Ellehammer' is a local project that connects businesses and primary and secondary schools with the aim of formulating problematizing projects that spring from the real world.

All pupils in Christian Black-Storm's ninth year, worked on developing projects for three local businesses that needed help solving a specific problem. The pupils were divided into smaller groups, one of which worked on an information campaign for Avedøre Wastewater Plant, another designed a waiting room for Hvidovre Hospital, and the third group designed an interactive bus stop with solar cells for Gaia Solar. The work was carried out in close collaboration with the companies. They provided access to staff members who could answer questions, they invited the pupils to visits, and they gave feedback once the pupil's projects had been handed in.

\section{'I'm not sure this should be measured in the same way that we measure everything else in primary and secondary school'.}

Christian Black-Storm, teacher

NEW ASSIGNMENTS, NEW HABITS

According to Christian Black-Storm, relating to what they are working on is exactly what teaches pupils to think differently. 'The innovative part of this project lies in the fact that they have to discuss what to do and how to solve a given problem', he says and explains that having to let go of a culture where both internal competition and doing things 'right' is usually high on the agenda is hard for the pupils. 'We have tried to create a platform where the pupils use one another - across groups as well. They have to reach a point when they no longer feel they have to keep thoughts close just because two groups are working on the same subject. It's all about sharing and developing'.

It can be a challenging process. In Christian Black-Storm's experience, the level of commitment and creativity rises remarkably once the pupils get started. 'They come up with some truly magnificent ideas! It becomes so much more real, because they work with 'live' cases; there are actually people out there who can use their ideas. We have put a lot of effort into explaining that the companies actually need their help. And that means a great deal.'

Christian Black-Storm explains that as their teacher, he has also been challenged in the process. His role changed because the assignments were set by people from outside the school. 'It freed up time for me to concentrate on bringing out the pupils' innovative skills by asking the right questions and helping them stay energized rather than assisting them in finding information, they could easily find themselves', he elaborates.

\section{INTANGIBLE EXAMS}

The process ended with an examination, where the pupils presented their projects in much they same way they would present a traditional project assignment. They were given marks based on the entire work process, the presentation itself and the product they had created. A marking process that was far from straightforward according to Christian Black-Storm, 'After all, we had to assess and mark some fairly intangible things'.

He believes that marking should be approached differently in future projects, 'We should set certain goals for the individual projects and then focus on their ability to reach those goals in our assessment. One assessment could then be that pupils in one group had to improve their collaborative skills while in another group they had to work more creatively. These are still rather intangible measures but that doesn't matter. I'm not sure this should be measured in the same way that we measure everything else in primary and secondary school'.

\section{ELEVER AF \\ ELLEHAMMER (STUDENTS OF \\ ELLEHAMMER)}

'Elever af Ellehammer' is a project organised by the municipality in which local businesses and secondary schools collaborate on concrete projects for older pupils. During the school year, a number of private and public businesses and institutions in Hvidovre Municipality meet with teachers from all the municipal schools to formulate cases based on information provided by the businesses, after which the cases are presented and can be incorporated into the project processes at the schools. The project also provides certain materials that schools can use as a point of departure throughout the process, including drafts of a project plan as well as exercises in idea generation and creative processes.

The project's name, Elever af Ellehammer, refers to the Danish inventor and aero-pioneer Jacob Ellehammer, and it reflects the project's original target subjects, namely the natural sciences. Over time though, the project frames have become more interdisciplinary. 


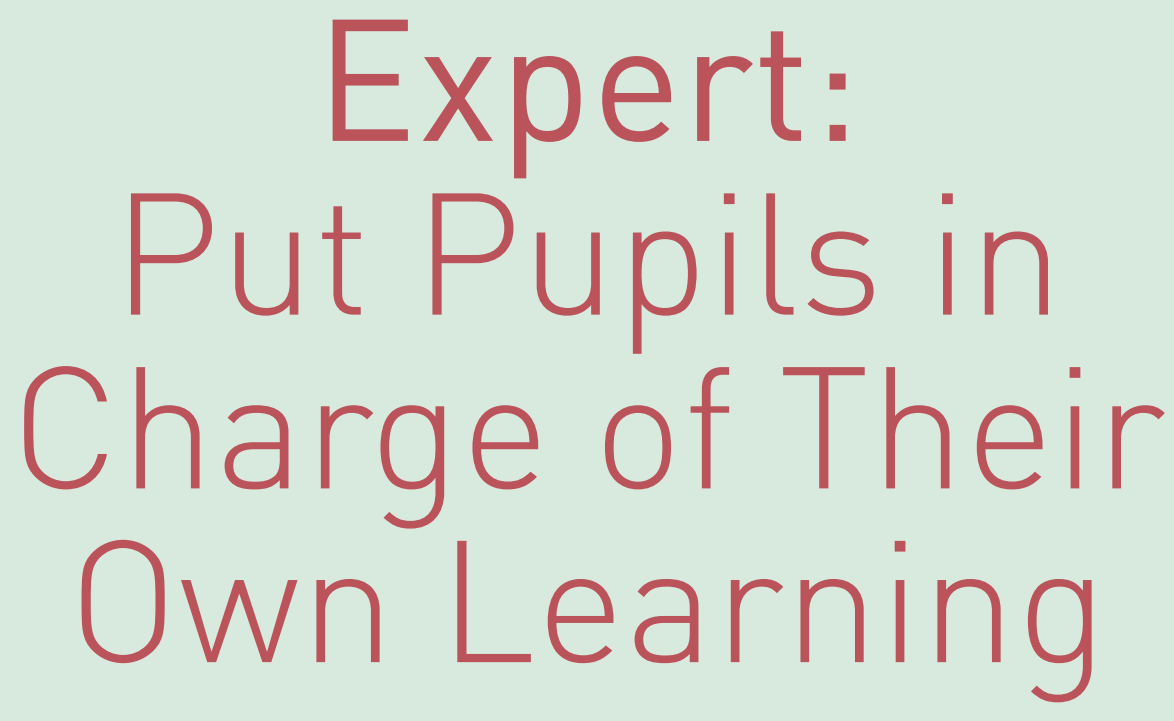

We asked Eva Leffler from Umeå University, Sweden, how she views entrepreneurship education in primary and secondary school. She is one of the leading experts in entrepreneurial learning in the Nordic Region and she wants teachers to use the pupils' interests and real problems as point of departure in order to make them entrepreneurs in their own learning process. 


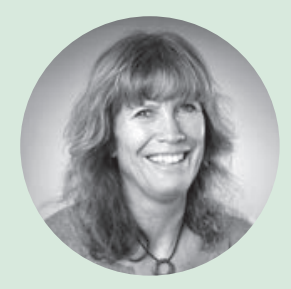

\section{WHO'S WHO: EVA LEFFLER}

* Assistant Professor of Pedagogy, Umeå University. Affiliated with the research areas Företagsamt Lärende och Entreprenörell Pedagogik (Enterprising Learning and Entrepreneurial Pedagogy).

* Her research focuses on entrepreneurship and enterprises in schools as well as entrepreneurial pedagogy in schools.

* Among other things, she has helped the Swedish Skolverket gather experiences with and communicating research into entrepreneurship in schools.

\section{Almost every Nordic country has, within the last few years, formulated political strategies for entrepreneurship in educa- tion. What kind of change is it that the politicians wish for?}

Encouraging entrepreneurship in schools has two different goals. One goal is securing a future where more and more people choose to become entrepreneurs and create their own jobs. And for that purpose, we teach children how to start and run a business with the aim of motivating some of them to do just that at some point in the future. The second goal is a pedagogical approach where you take the children's interests and real problems as your point of departure in order to make them entrepreneurs in their own learning process. The aim here is to enhance their motivation to learn and thus their learning outcome.

In order to practice the latter, you need to fundamentally change the school culture. When we look at how most primary and secondary schools are organised, the logic inherent in the labour market of the industrial society is still very much a deciding factor. In numerous schools, the first bell sounds at 8:00 AM, the lessons are 45 minutes long and pupils are taught one subject at a time. The days all follow a specific time table, and how many pages you have to 'cover' has been decided in advance. Rows of tables and chairs do not really invite pupils and teacher to collabo- rate and learn from one another. In other words, the systems that govern the teaching and the organisation of the school are antiquated. And we have to change this, if we want the school to educate our children and enable them to live in a constantly changing society.

Is entrepreneurship not merely another word for something we have always done in primary and secondary schools in the Nordic Region?

No, I don't think so - but it's important to understand that entrepreneurship in education contains exactly these two components, and we need to be conscious of the goals attached to the two components, respectively.

I am particularly concerned with entrepreneurial learning, and many teachers believe that they already are, and in fact always have included pupils and given them responsibility. However, the new aspect is that it's no longer enough to say so; they now have to explain and show how they go about it. Whether it works, we'll know from the pupils. The test is whether or not they find attending school meaningful, and if they know what they have to learn as well as why they have to learn it.

\section{What is it specifically that teachers must do differently?}

First of all, you can start by opening up the classroom, inviting other teachers in as critical and constructive observers who can provide feedback in relation to whether or not you actually involve pupils as much and as early on as you possibly can. There is great potential in cultivating what I call cooperation, as a framework for this kind of development.

Furthermore, teachers can work towards relingquishing their focus on what is right or wrong. Of course, there are incidents when it's decisive if a pupil answers a question rightly or wrongly, but even in maths there are numerous examples of learning situations where it's of greater value to concentrate on the learning process, e.g. different methods of calculating something, than on whether or not pupils reach the correct result.

Finally, it is about becoming braver, in the sense that you dare leave your planning behind and grab the ball when pupils reveal an increased interest in something. In much the same way, it is also about locating spaces for learning that are outside the classroom, by for example collaborating with local businesses.

Research shows that even little changes can have a huge impact. As soon as teachers become aware of how they work, start to ask questions and involve the pupils etc. that's when it really takes off.

\section{What should administration do?}

Headmasters and -mistresses must front change and that is a huge task. Change at each individual school must take its point of departure in the utilization of the resources and possibilities that pupils, teachers, parents and surroundings etc. constitute. This means that administration must themselves approach the task in an entrepreneurial manner by considering, for example: What kind of school structure do we have? What options do we have? What changes are necessary to achieve the goals we have set for our school?

\section{Do we know that it works?}

Paradoxically, we know quite a bit about how teachers experience entrepreneurship education but very little about how entrepreneurial learning affects pupils.

What we are relying on for the time being is primarily evaluation reports from different projects that show that pupils experience taking responsibility as meaningful and stimulating. We need studies though, where we, over a longer period, follow the development of select pupils who encounter entrepreneurial pedagogy in school, to be able to say what the long-term effects may be. 


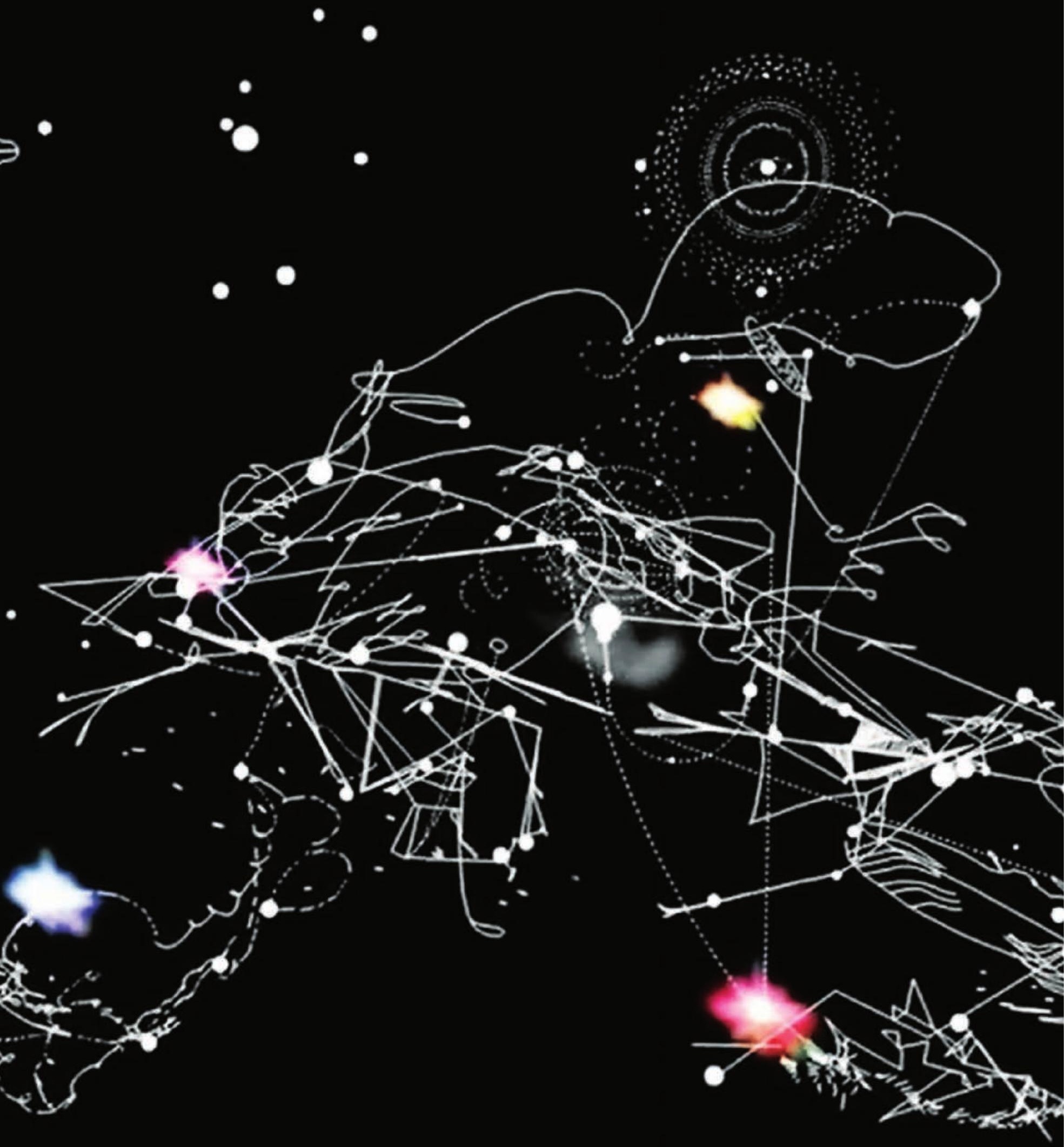

By using apps for iPads the pupils are afforded the opportunity to experience how music can also be expressed visually. Pupils can also work interactively and create new pictures with the music. The photograph is from a Biophilia app. 

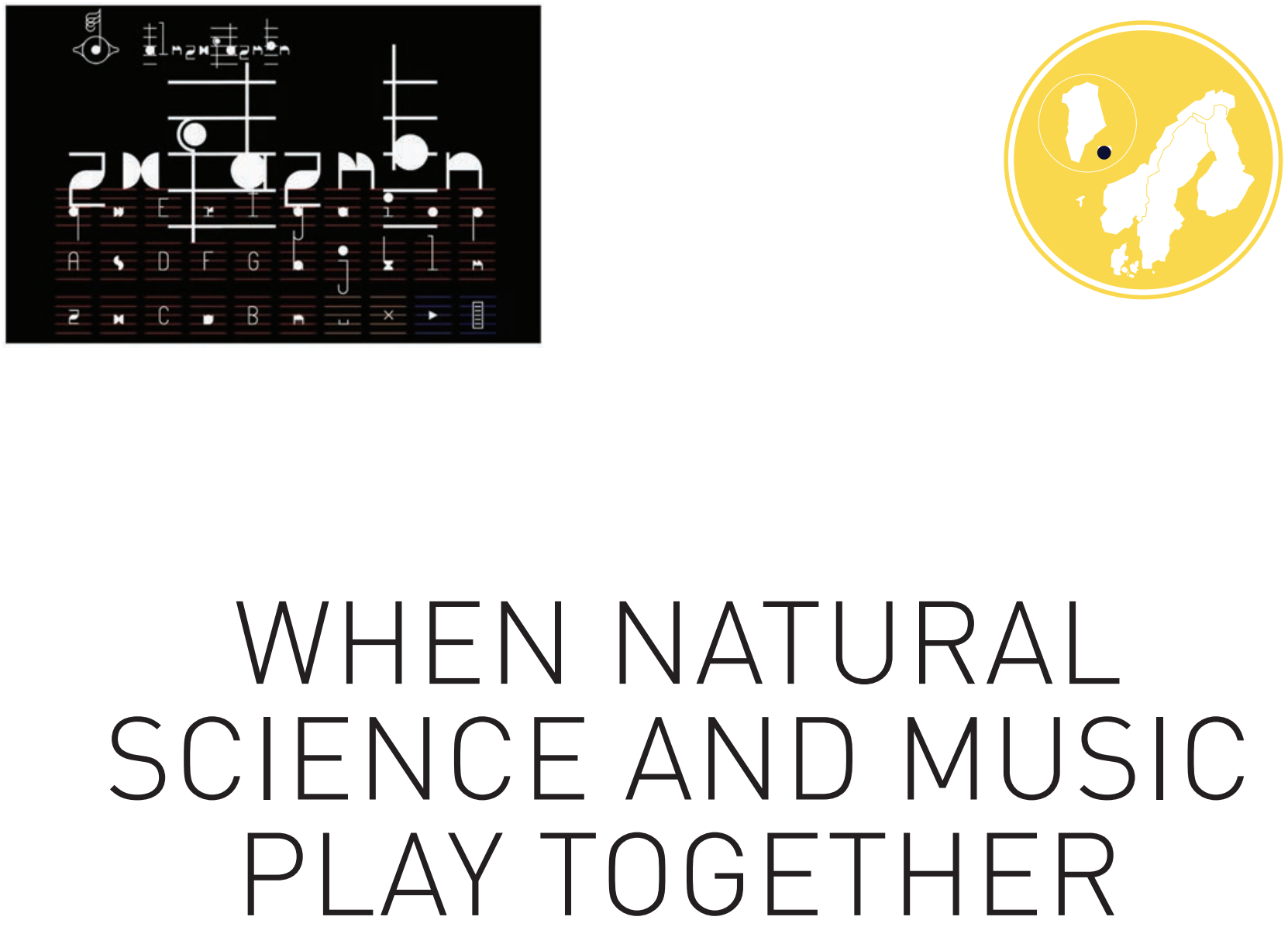

The interdisciplinary Biophilila Educational Program has developed an education and research method focused on creativity. The project, which is based on singer Björk's album Biophilia, is particularly concerned with the connection between music and natural science as well as the use of visual learning methods. The pupils get a sense of the many different ways in which learning can take place.

'L earning to read and write is incredibly important - and should not be dismissed offhand. On the contrary, Biophilia offers a new approach to teaching. For the last 300 years, the classroom has looked more or less the same. It is square and contains tables and chairs. But we have entered the $21^{\text {st }}$ century now; the world has become smaller because of the Internet, and borders are evaporating. In Biophilia we also try to break down borders. You can read about the solar system in a book, but you can also experience it in three dimensions. There isn't one single way of learning'.
These are the words of Arnfríður Sólrún Valdimarsdóttir. She is one of the project managers of the Biophilia Educational Program. Since its implementation in 2011, the program has been so successful that it has become one of the key projects under the Icelandic leadership of the Nordic Minister's Council in 2014.

\section{THE WOLRD'S FIRST APP-ALBUM}

Biophilia Educational Program is a multimedia project that combines music, technology and the natural sciences, and it came into being through an unorthodox collaboration between the Icelandic singer
BIOPHILIA EDUCATIONAL PROGRAM

You find teaching materials as well as additional information about the program at Biophilia Educational Program's website, biophiliaeducational.org. Among other things, you can watch a video from one of the program's workshops in Reykjavík. Currently, both website and program is undergoing substantial development. 


\section{'I also had to learn new things. Because everything was so new, we were all at the same level. I was never very good at natural sciences in school, but learning about physical phenomena, I was able to see music, which is after all my home turf, from another perspective'.}

Elfa Lilja Gísladóttir, music teacher
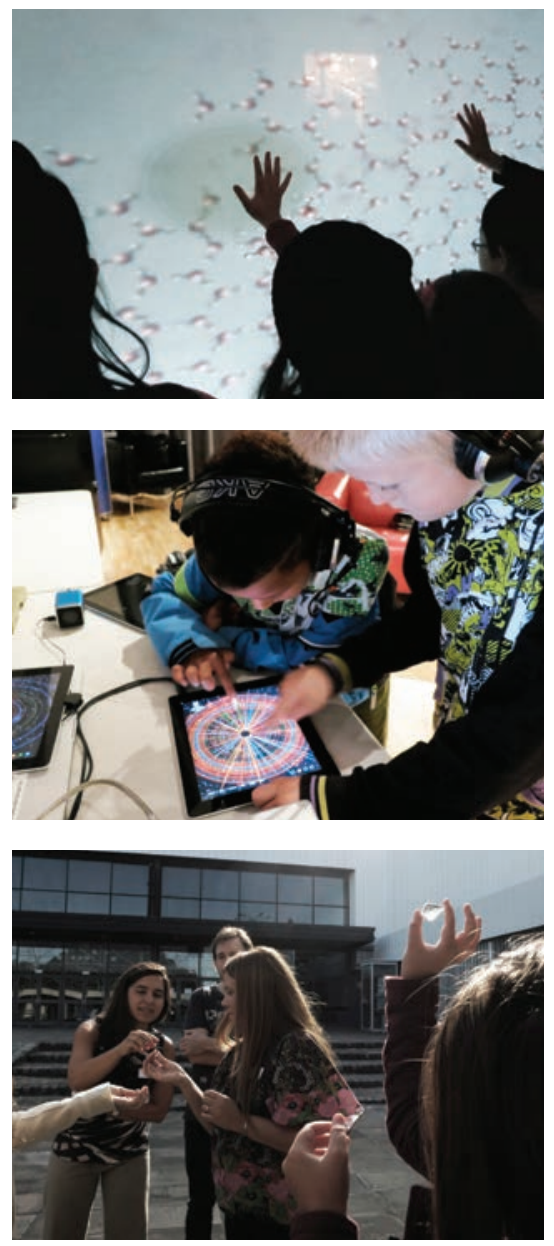

Biophilia Educational Program wrestles traditional subject boundaries and approaches to teaching in primary and secondary school. They work multi-medially by coupling natural sciences with music.
Björk, the University of Iceland and Reykjavík Municipality, which is highly indicative of the project's interdisciplinary core. The project takes its point of departure in Björk's album Biophilia from 2011, the world's first app-album. All the songs on the album have an individual iPad-application, which in a teaching situation allows the pupils to experience the music both visually and interactively. It accentuates the threads between music and natural sciences in particular. By way of example, pupils learn that lightning also constitutes a chord, and that one of the songs on Biophilia is about DNA.

The overall idea is about developing a method of teaching and research based on creativity. 'Creativity as a learning tool' is the project's motto. In other words, the Biophilia Educational Program is a pedagogical program and the forces behind greatly encourage interdisciplinary participation as well as collaboration across age groups.

\section{THE TEACHER AS PUPIL}

Music teacher Elfa Lilja Gísladóttir from the school Dalskóli in Reykjavík was one of the first teachers to join the project; she took part in the very first workshop back in 2011. The program provided her with a new perspective on her own subject as well as a new approach to teaching. 'We all learn in different ways. The good thing about Biophilia was that both teachers and pupils had so many options. My own background is in music, but this taught me something about the natural sciences. There were so many ways of engaging the pupils, because they could choose their own approach', she says.

She also points to how the interdisciplinary interaction as well as the multimedia nature of the project made every- body feel on par. 'I also had to learn new things. Because everything was so new, we were all at the same level. I was never very good at natural sciences in school, but learning about physical phenomena I was able to see music, which is after all my home turf, from another perspective'. The program's effect on the pupils is visible when you look at what songs they wish to sing. 'They experience the songs in a new way, because they have learned to also view music from a natural science angle. What does lightning and arpeggio tunes (when a chord is played tone by tone rather than at the same time, ed.) have in common? Or what does a pendulum and part-singing have in common?' she elaborates.

\section{BIOPHILIA AS A PERSPECTIVE}

The program has helped point out new possibilities for the children. 'At my school, we were already engaged in breaking up traditional teaching methods. We teach through art and incorporate 'heart and hand', which means learning a curriculum using all our senses. Working with Biophilia, my pupils met with a format they were already slightly familiar with from their own school, where we try to introduce them to new ways of learning all the time. They noticed numerous connections to what they were being taught in school and that gave them a sense of the school literally being a part of the world', Elfa Lilja Gísladóttir says. She believes that the program is a highly welcome supplement to existing methods of teaching. 'It was not as if pupils returned to school and had changed their personality, but they have been given an important new perspective and they are open to the many new ways of working'. 


\section{WE HAVE MANY NAMES FOR THE THINGS WE LOVE}

Traditionally, entrepreneurship and primary and secondary schools are not two entities we associate with one another - not in practice and even less so linguistically. However, when we in the Nordic Region increase our focus on the interconnectivity between the two terms and their inherent worlds, a need arises for a determination of how to speak about the many different ways this can be achieved.

In this magazine, we have left it to the individual participants to define and describe how they themselves experience entrepreneurship education in schools. The pivotal point has been that they recognize the connection between the two worlds and terms.

But it is not merely the content we afford the terminologies that vary from place to place, as is ever visible in a Nordic context, something happens to the words themselves when they move across borders.

\section{Foretagsomhed / företag / enterprise / fyrirtæki / yritteliäs}
Kreativitet / kreativitet / kreativitet / sköpun / luovuus
Innovation / innovasjon / innovation / nýsköpun / innovaatio
Entreprenørskab / entreprenørskap / företagande / frumkvöđlastarfsemi / yrittäjyys
Iværksætteri / entreprenørskap / entreprenörskap / frumkvöđlastarfsemi / yrittäjyys



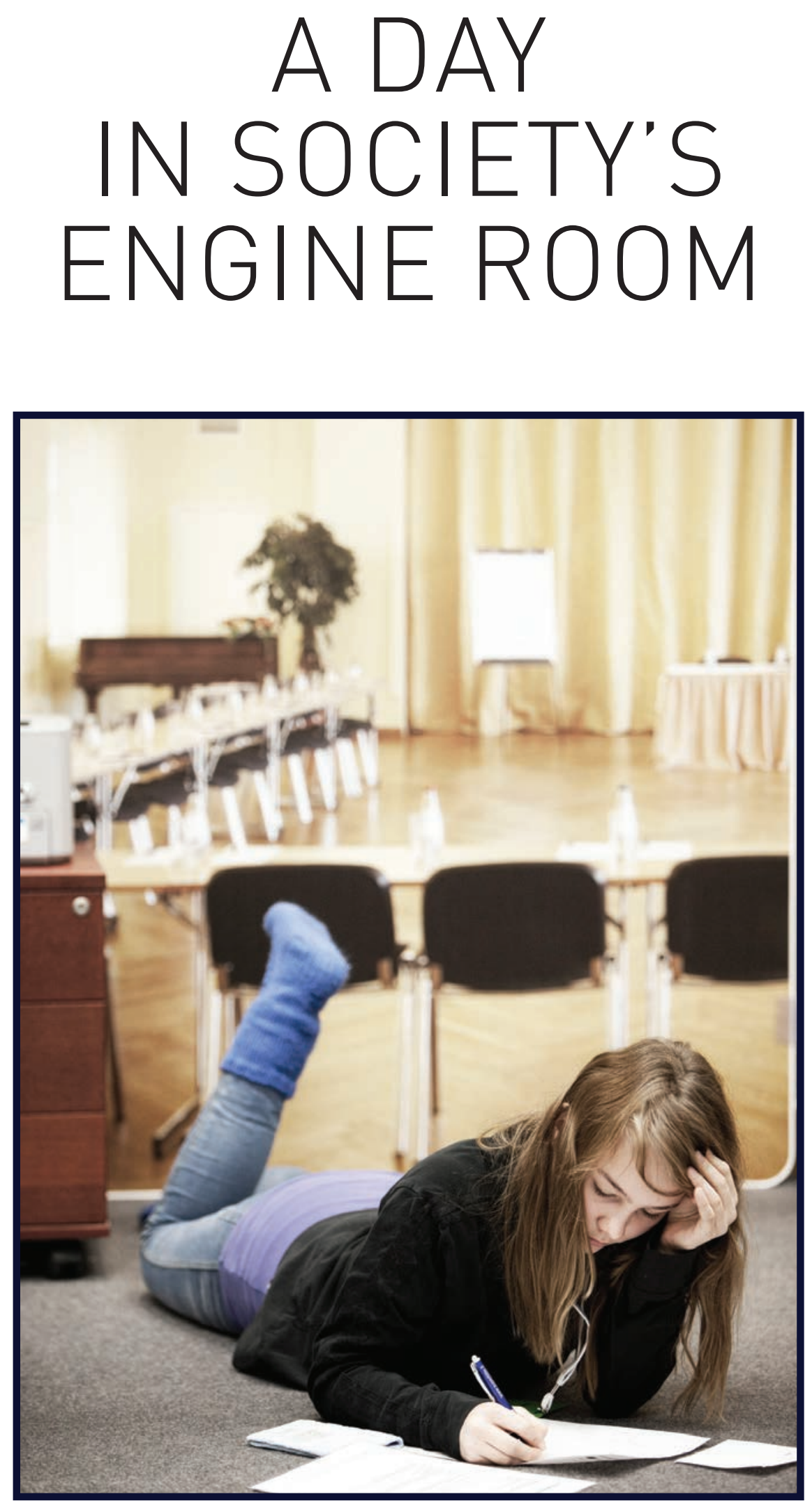

In Yrityskylä, pupils are asked to try their hand at 'adult living', i.e. going to work, being paid a given wage, and signing the necessary contracts, in an effort to enhance their understanding of the society that surrounds them. 


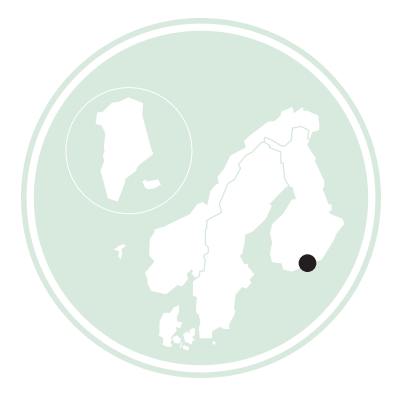

Ever since 2010, a new learning concept has surfaced in different areas of Finland. In the miniature town Yrityskylä, pupils get a taste of adult life on a daily basis, as they have to contemplate work and finances - and it is much more popular among both teachers and pupils than you might have initially suspected.

$\mathrm{T}$ he till tinkles in the supermarket and the postwoman is busy distributing the day's mail. The bank handles a loan for a newly started business, while two girlfriends spend all of their wages at a café in town. At the other end of town, the managing directors of two of the town's larger business are negotiating a contract, which they will subsequently have to present to their employees.

Offhand, it could be the reality in any larger town, but it is in fact a snapshot from a day in the life of 70 pupils at Yrityskylä.

Yrityskylä is a practical learning tool, where pupils in the sixth year use roleplaying to gain concrete experiences with a working life as well as their societal role as consumers and taxpayers. In a 500 square metre hall, designed as a miniature version of a town with a selection of the most important facilities, institutions and 15 different workplaces, each pupil is offered a job following a job interview with their teacher. And then it is off to work. The bank will provide start-up capital for the businesses and the pupils will start working from the assignment profile suitable to their position. The assignment profiles are made as true-to-life as possible through close collaboration with the local businesses that the pupils know from their everyday lives.

\section{PUPILS HAVE TO UNDERSTAND SOCIETY}

Yrityskylä came to life approximately five years ago, when Tomi Alakski, who then taught fifth year pupils, decided that something had to be done about the lack of knowledge of the surrounding society his pupils displayed. He saw opportunities in establishing a closer collaboration with local business and together with the nonprofit organisation Economic Information Office (TAT) in Helsinki, he developed the idea of Yrityskylä as well as a mobile concept that tours the country.

In order to enhance the pupils' understanding of the society around them, and of which they themselves are a part, Yrityskylä is so much more than just a one-day school trip. Back at the schools, the visits are integrated into the teaching through 10-module courses, where each taught subject engages in socially relevant assignments. In Finnish, for example, the pupils will write job applications while in art classes they will analyse advertisements. One of the goals in maths is creating an awareness of VAT and taxes, and to do so, the pupils bring in their parents' receipts in order to calculate how a specific price is arrived at. And so, before they visit Yrityskylä to get a taste of adult life for a day, the pupils will already have worked with both entrepreneurship and citizenship in various subjects.

\section{THE TEACHERS CAN DO IT THEMSELVES}

An important aspect of Yrityskylä is that although the framework is provided, the teachers have a lot of influence on the content. For example Janne Kylli, who recently spent a day at Yrityskylä with his sixth year pupils, decided that the pupils would conduct the job interviews, alternating between being managing directors and job applicants. He explains that it was a way of teaching pupils about the differ- ent roles, expectations and cultures they would encounter in a workplace.

This view is backed up by Tomi Alakoski, who generally believes that there are many ways of expanding the pupils' societal horizon - both with and without Yrityskylä.

'While Yrityskylä has enabled us to develop a complete package in relation to these courses, and they have been well received by pupils as well as teachers and parents, it is also important to emphasise that providing the framework that we have here, is not vital for the learning results of such courses. It is something that a team at any school can get together to plan. The teachers can start by mapping the interesting local businesses and organisations and then invite them to a meeting to explain their teaching methods - and then they can share their views on how a collaboration could take shape', he concludes.

\section{ENTERPRENEURSHIP ON THE TIMETABLE}

In Finnish primary and secondary schools, entrepreneurship and citizenship are themes that must be included in all taught subjects. This is the aim that Yrityskylä is trying to oblige by providing a framework where pupils can develop competences in relation to initiation skills, problem solving and negotiation techniques. 


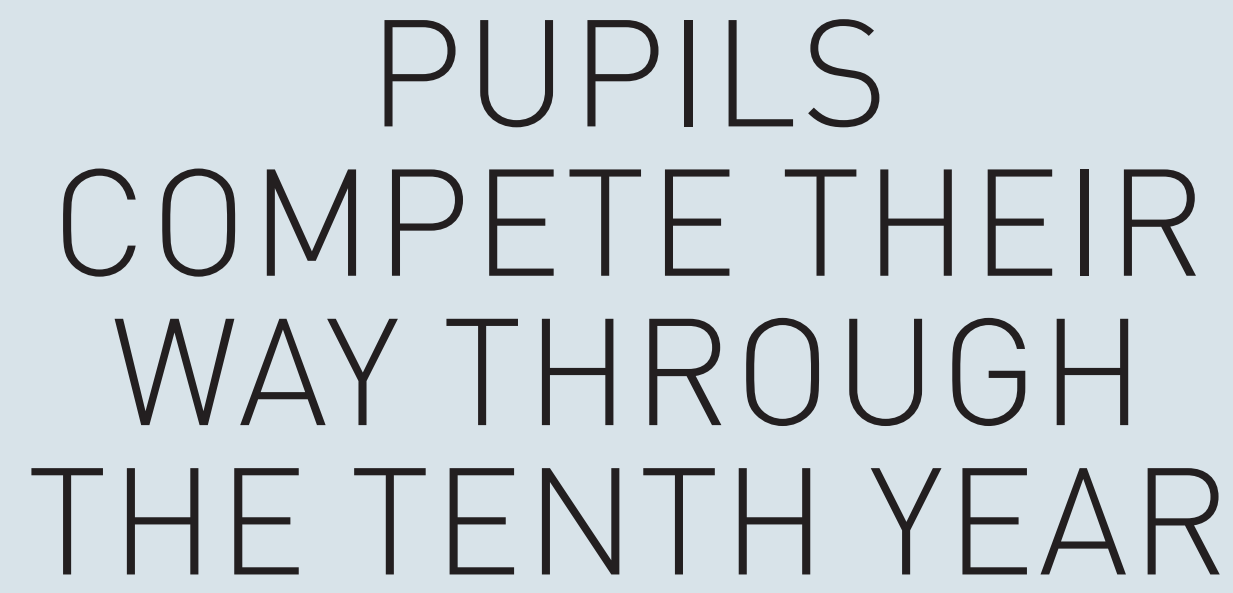

An entire school year is dedicated to hands-on experience with entrepreneurship - it is a new approach to teaching the tenth year that emerged on the Faroe Islands four years ago. A teacher describes how competitions used as a pedagogical tool challenges the idea of equality in primary and secondary school.

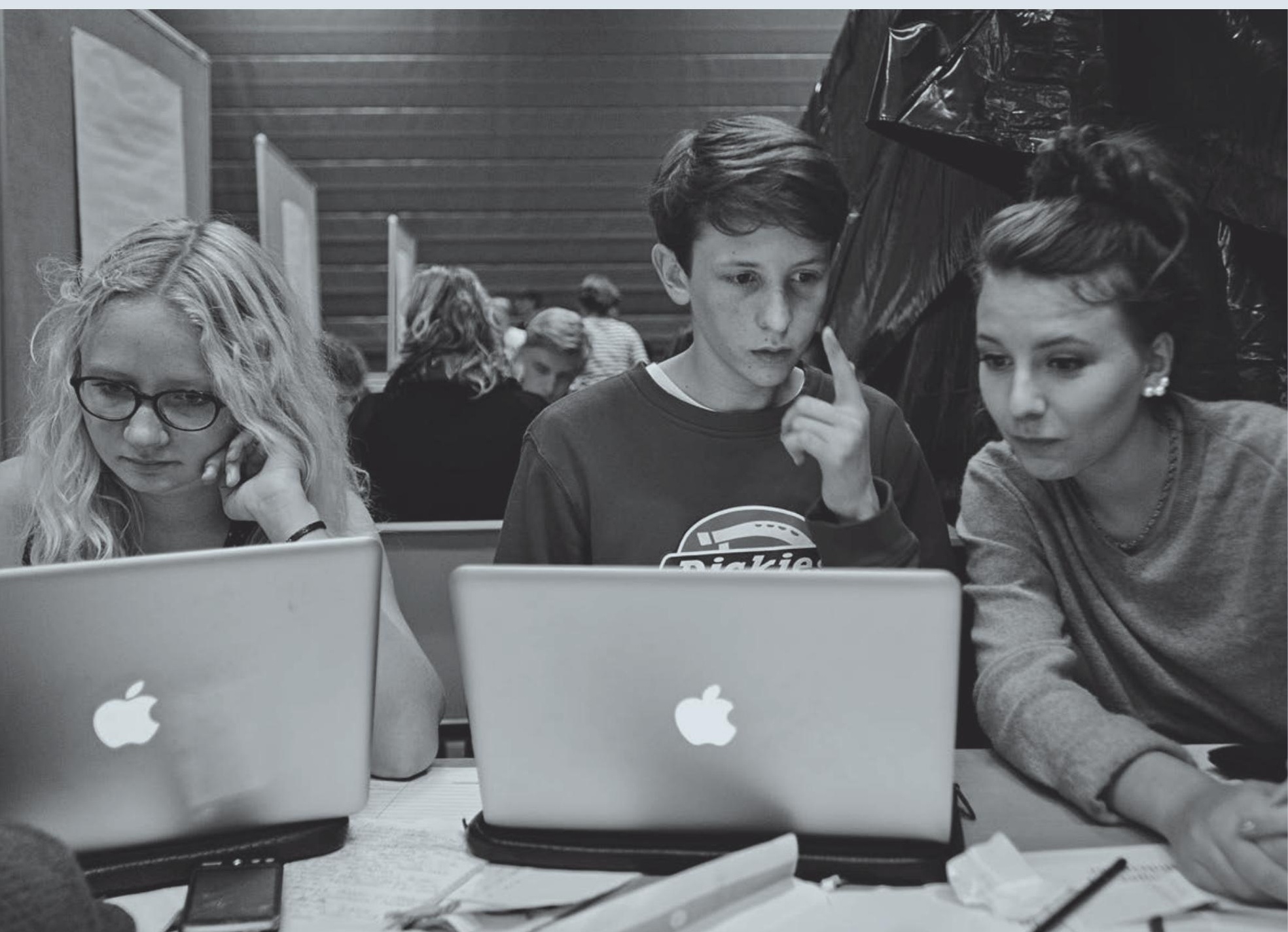




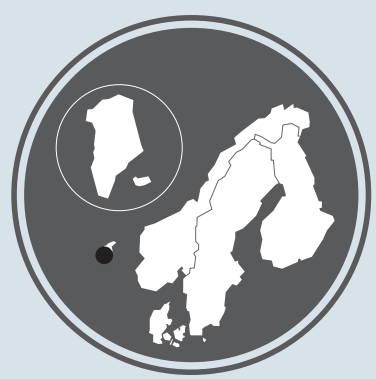

$\mathrm{I}$

t gave rise to great pride when three students from a business college on the Faroe Islands won the 2013 Danish Entrepreneurship Championship ahead of 33 competing teams for their Atlantic Sea Salt business. They produce and sell flavoured organic salt extracted from the Atlantic Sea around the Faroe Islands. The people behind the world-renowned gourmet restaurant Noma were among those impressed by the quality of the salt and they immediately signed up as customers. The company brought even more joy to the Faroe Islands as they competed in the European Championship in London with the participation of 35 countries and managed to secure yet another prize for the islands; a special award for the most efficient and creative business model.

For teachers, pupils and the administration at the school Nam X, the awards are particularly important, because the three successful young men are former pupils at the school and their success is regarded as a result of the schools relentless efforts to teach the pupils entrepreneurship.

\section{THE ELIMINATION PROCESS}

Within the last four years, four out of twenty schools in the Faroe Islands have initiated entrepreneurial lines in their tenth year groups. What makes these tenth years markedly different from the traditional tenth year is the fact that competition constitutes the pivotal focus point in the learning process.

At the very beginning of the school year, in September, 500 pupils take part in an innovation camp for ninth- and tenthyear pupils. After a few initial inspirational talks the pupils are tasked with carrying through an innovation process in three stages: brainstorming, refining ideas and sales. The day ends with the pupils presenting their idea as a business proposal to a panel of judges who subsequently select a winner. In the following months, the pupils will take part in more camps, about economy, management, sales and performance. The entire process ends in a grand finale in February with the presence of among others the minister of culture, and the number of participants will by this time have shrunk to approximately 30 out of the original 500 .

\section{'The law does state that primary and secondary school should be for everyone, but that doesn't mean that everybody has to be treated the same way and that all must share the exact same experiences'.}

Ingi á Smid, teacher

The camp is organised and completed by Íverksetarahúsið, which since it opened in 2007 has worked to encourage entrepreneurship in the Faroe Islands. Rani Nolsøe, who heads Íverksetarahúsið and is the driving force behind the organising of the yearly innovation camps, emphasises that the aim is not for every pupil to choose a career as an entrepreneur, 'All pupils are welcome, but we have quite deliberately constructed the camps as an elimination process where teachers in the initial workshops can find out who among the pupils are best suited to continue in the competition and who are the most dedicated'. According to Ingi á Smid, who teaches entrepreneurship at Nam X, there are 5-6 pupils in a year who have the potential to continue as entrepreneurs. 'If we manage to light a fuse in some of the pu- pils and increase their faith in themselves and their strengths, and if a few of them actually manage to realise their dreams, then I'll consider the teaching successful'. At the same time, he finds that all pupils, including those who do not have the potential for winning competitions, gain much from simply participating in the initial camp. 'It is highly educational and motivating for all of them. They become so much better at taking initiative and stepping up'.

\section{COMPETITION DOES NOT EQUAL BLIND EGOTISM}

Experiences at Nam X reveal that allowing pupils to compete can be considered a rather controversial pedagogical tool. However, Ingi á Smid emphasises that competing has an important pedagogical aim when teaching pupils at that age, i.e. in the tenth year. 'The law does state that primary and secondary school should be for everyone, but that doesn't mean that everybody has to be treated the same way and that all must share the exact same experiences. I have yet to come across one single pupil who became depressed on account of a classmate winning. When you are 15-17-years-old, you are mature enough to handle the fact that we are all different and we all have different gifts', Ingi á Smid explains. He continues by stating that the teachers are very aware of the fact that all pupils must be made to feel part of the projects they participate in and that what they do is meaningful. 'As teachers we are sparring partners. We launch the projects and closely guide the pupils throughout the process', he says.

That the main prize in the initial innovation camp is a hamper with sweets is no coincidence - neither does it express a lack of funding. That prize sends an important message to the pupils, namely that the process is much more important than the goal, Rani Nolsøe points out. 


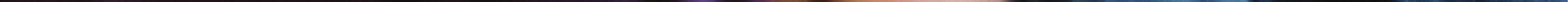




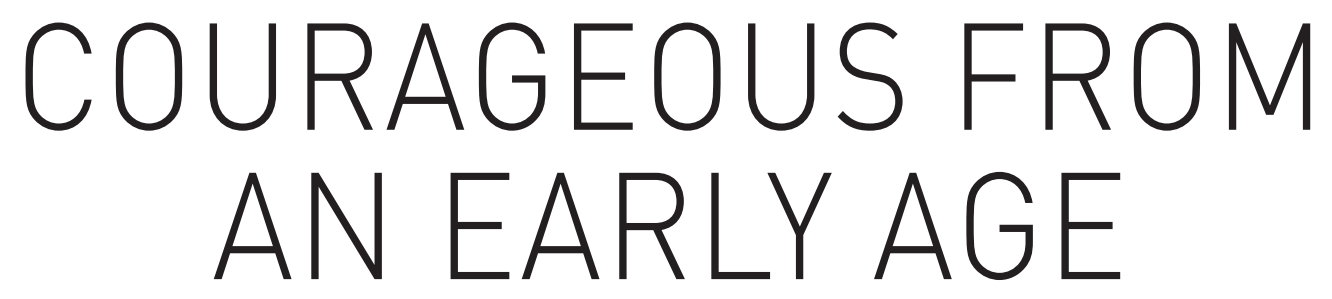

In a small village school in Røsvik in the North of Norway, they have created a 'lyttekrok' (listening corner) for pupils in the first to fourth year, a place where they practice listening to one another and talking about what they find important. It gives them courage and teaches them to understand that a good idea needs to be supplemented with words if it is to grow.

$\mathrm{L}$ istening can be really hard when you have so much you want to tell. And at other times it can be so difficult to say anything at all when there are suddenly so many people listening. This is something most of us are familiar with, children as well as adults.

For several years, Røsvik skole (school) has worked to solve these kinds of communicative conundrums from an early age. Since 2005, the school has deliberately included entrepreneurship in their teaching, but even before then, the teachers had established what they called a 'lyttekrok' (listening corner) for all pupils in the first to fourth year. Everyday, teachers and pupils spend the first 25 minutes in the listening corner, going over the day, and then one of the pupils will sit in the centre of the circle and share something with the others. What the pupil chooses to share is of less importance - it simply has to be something that occupies the pupil speaking. Having shared her or his story, the pupil will also act as moderator, deciding on who will speak when.

A HUGE STEP FOR THE SMALL ONES For some pupils the butterflies in their stomach grow so large when they have to speak in public that uttering a single sentence can be prove very trying, Birgitte Gleinsvåg, entrepreneurship teacher at the school, explains. In order to help them along, the adults will ask short, simple questions that they know the pupils are capable of answering, followed by much appraisal. 'Everybody likes being told that they are good at something and this will increase their well-being, make them dare to say more, and eventually they'll want to speak for themselves', she elaborates.

At the same time, however, teachers are in charge of the time spent in the listening corner to ensure that all pupils get a chance to speak and listen to others. 'In the listening corner, we always discuss matters in a democratic manner and we keep a very tight structure. Everybody has to wait her or his turn and everybody will get to moderate the discussion at some point. Because the pupils have practiced it from an early age, they are used to having a say and being heard - but they are also used to being rejected and given constructive criticism. This helps them in their work, both in and outside of school. They learn to accept and respect the opinions of others'.

\section{AN IDEA MUST BE SHARED IN ORDER TO GROW}

At the school, they work strategically with entrepreneurship education across all year groups and in many different ways. Whereas the listening corner has a more 'soft' focus in relation to entrepreneurial competences, such as learning how to take responsibility, wait your turn, or finding the courage to reveal that you have something to say, the focus in the more senior years includes specific entrepreneurial skills such as starting your own business.
Here the social and communicative skills that the pupils have developed from the very early years become crucial when for example they have to present their ideas to one another or make inquiries outside the school. And in this way, the listening corner becomes the first step in a complete school process, in which entrepreneurial skills constitute a main mission.

What the school wishes to accomplish, according to Birgitte Gleinvåg, is that pupils from the first to tenth year develop life skills that will enable them to stand on their own two feet in adulthood. 'Skills such as taking responsibility, being able to collaborate with others, being creative, thinking innovatively, being aware of yourself and others, feeling confident in conversation, taking risks, seeing opportunities and doing something about them, is something we are very concerned that our pupils should learn', she explains. 'Standing up in front of a large gathering, be it in a church or a workplace, may be a rather abstract concept, but learning how to manage it, is really important'.

In the listening corner, this is exactly what they practice. 'The sooner you learn to stand up and speak in front of others, the better. It must be learnt from a very early age, so that daring becomes a natural part of their behaviour', she elaborates. Even from a very tender age, pupils must learn that they may very well have many great ideas, but unless you are able to share them with others, they may never come to anything. 


\section{A TASTE OF THE FUTURE}

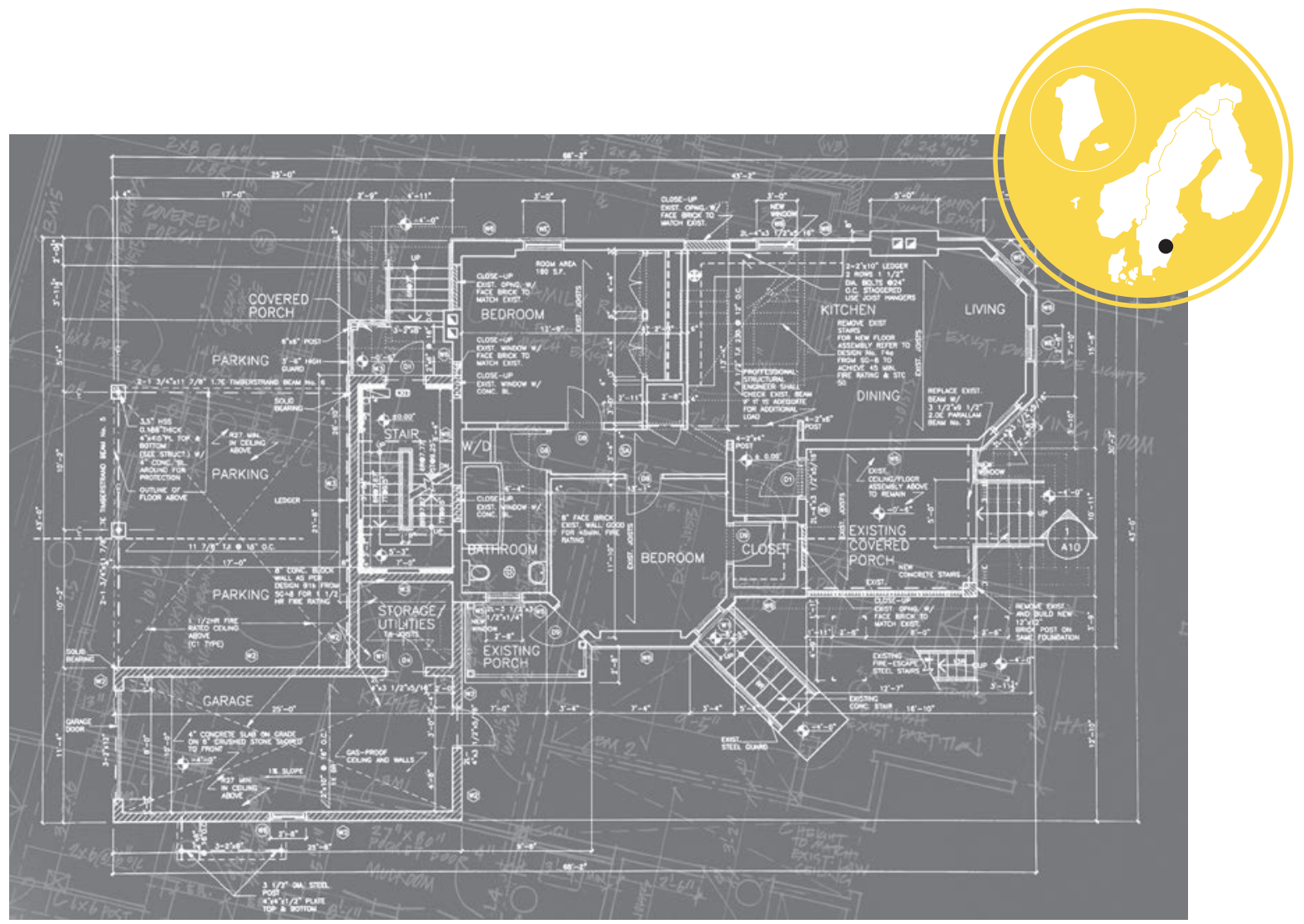

A mere four years ago, Alléskolan in Southern Sweden's Åtvidaberg were struggling with pupils who found reaching their goals increasingly difficult. As part of a grander strategic focus on entrepreneurship, they began systematically sending both pupils and teachers off on business visits in the local neighbourhood. 
'W elcome to Alléskolan - a school with drive (framåtanda)' it states on the Southern Swedish school's website. The term 'drive' includes both enterprise and ambition and today, there is absolutely no doubt that this is far from just another slogan hovering in cyber space.

However, this was not always the case. Åtvidaberg is an old industrial town, home to the local metal industries since medieval times. For one generation after another, an unskilled job in the mining industry on completion of their compulsory schooling was the natural choice for most. And up until four years ago, this culture was still firmly embedded in the local school. Teachers and administration battled with an increasing number of pupils not reaching their targets as they lacked the motivation to even attend school. It was highly unsatisfactory to watch pupils being less than properly prepared to choose an education, which might result in a good job once they finished school, headmaster Hans Grimsell explains. 'Getting a thirteenyear-old to think long-term can be quite a challenge: 'If you concentrate on this you'll be really pleased when you reach twenty'. When you're thirteen, you want things to be good for you now', he elaborates.

At Alléskolan they then decided to work more strategically with entrepreneurship education, by among other things organising visits to the local businesses. The aim was to get the pupils to reflect on their understanding of what being part of a workplace and holding down a job that demands further education meant.

\section{BUSINESSES SEEN FROM THE INSIDE}

What the school learnt from these initial visits, which were organised much along the lines of traditional work experience, was that the pupils basically learned 'how to become a good worker', Hans Grimsell says. However, at the school, they quickly realised that they had to come up with a new strategy, if the pupils were to gain something more from the visits.

Today, their collaboration with local businesses is closer and they engage the pupils to a much greater degree. All pupils at the school, which comprises years 7-9, visit several different businesses in the course of a year, and for four to six weeks, they work in groups and help a specific company prepare a stand for a big business fair. The assignment includes preparing a business visit with the aid of a teacher, coming up with their own questions for the employees and the management, and finally they have to gather material for the stand.

\section{'Getting a thirteen-year-old to think long-term can be quite a challenge: 'If you concentrate on this you'll be really pleased when you reach twenty'. When you're thirteen, you want things to be good for you now'.}

Hans Grimsell, headmaster

'The pupils have absolutely no idea what a modern business looks like. By way of example, many pupils believe that the welding industry consists of dirty jobs that are badly paid. However, once they venture out and actually see the many different skills in demand in that line of business, including engineering, they may discover that 'Ah, it is a clean job, and I can actually make lots of money", Hans Grimsell explains.

One of the biggest differences between then and now is that now there is room for courage, risk taking and dynamism. 'School can be a tough place if you are a more dynamic person. Pupils with those abilities are often dismissed as 'trouble'. But once they encounter business life, they receive positive feedback and experience that dynamism has value in certain contexts. And on the other hand, many employees have also shared with the pupils the wish that they had learned a foreign language when they were still at school', Hans Grimsell says.

\section{AN EYE OPENER}

Collaborating with local businesses has also changed the daily routine for the teachers. Not least because they also repeatedly visit the different businesses, following up with a monthly workshop where they exchange experiences and ideas in relation to for example specific methods a business has used to solve a problem and which may eventually be of use in a teaching situation.

Annika Lindh, who teaches Swedish and needlecraft, has noticed that both her and her colleagues have begun talking in a different way. Whereas there used to be a tendency to stand your own ground, ideas now float freely around the workshops. 'I've made lots of new contacts through visits to local businesses and I'll be able to use them for many years to come, in case either my pupils or I myself come up with an idea for a project', she states.

According to Hans Grimsell, the business visits have been an eye opener for pupils as well as teachers. The pupils' choice of youth education is much more qualified now, their results have greatly improved and the teachers have a much more profound knowledge of how a business actually operates. Now, in Hans Grimsell's opinion, the teachers are less likely to encourage the pupils to go in a certain direction: 'It's about showing the pupils that they have a choice'.

\section{ALLÉSKOLAN AND FRAMTIDSFRÖN}

Alléskolan is in the province of Östergötland, which according to the EU supported organisation Create holds a unique position in terms of entrepreneurship education in primary and secondary schools, not least due to the non-profit organisation called FramtidsFrön. In collaboration with Young Enterprise, FramtidsFrön has developed guidelines for entrepreneurship education in schools. Guidelines that Alléskolan also use. FramtidsFrön offer workshops, inspirational material and support for teachers working with entrepreneurship - and always with a point of departure in current curriculum. For more information please see: www.framtidsfron.se 


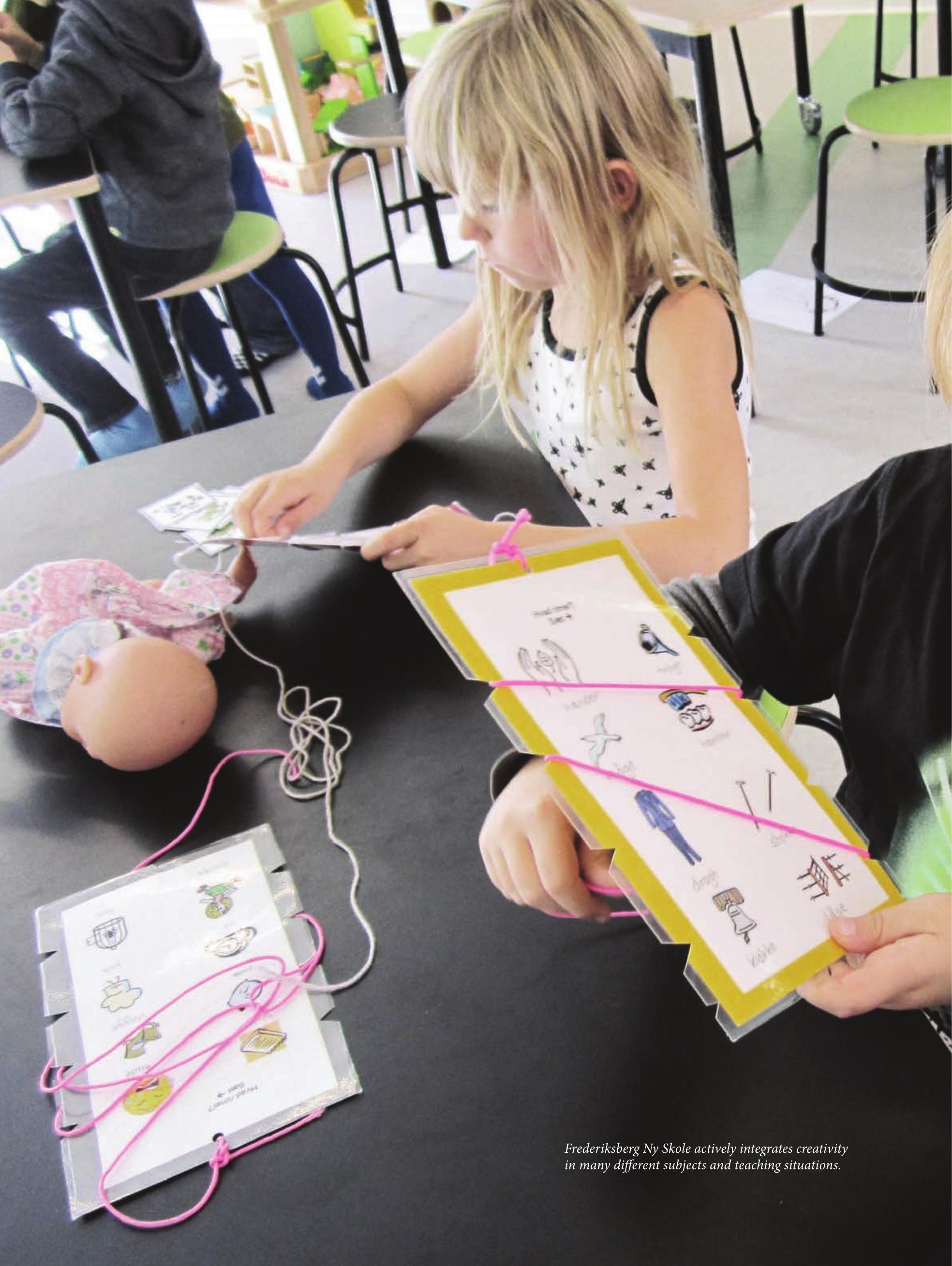





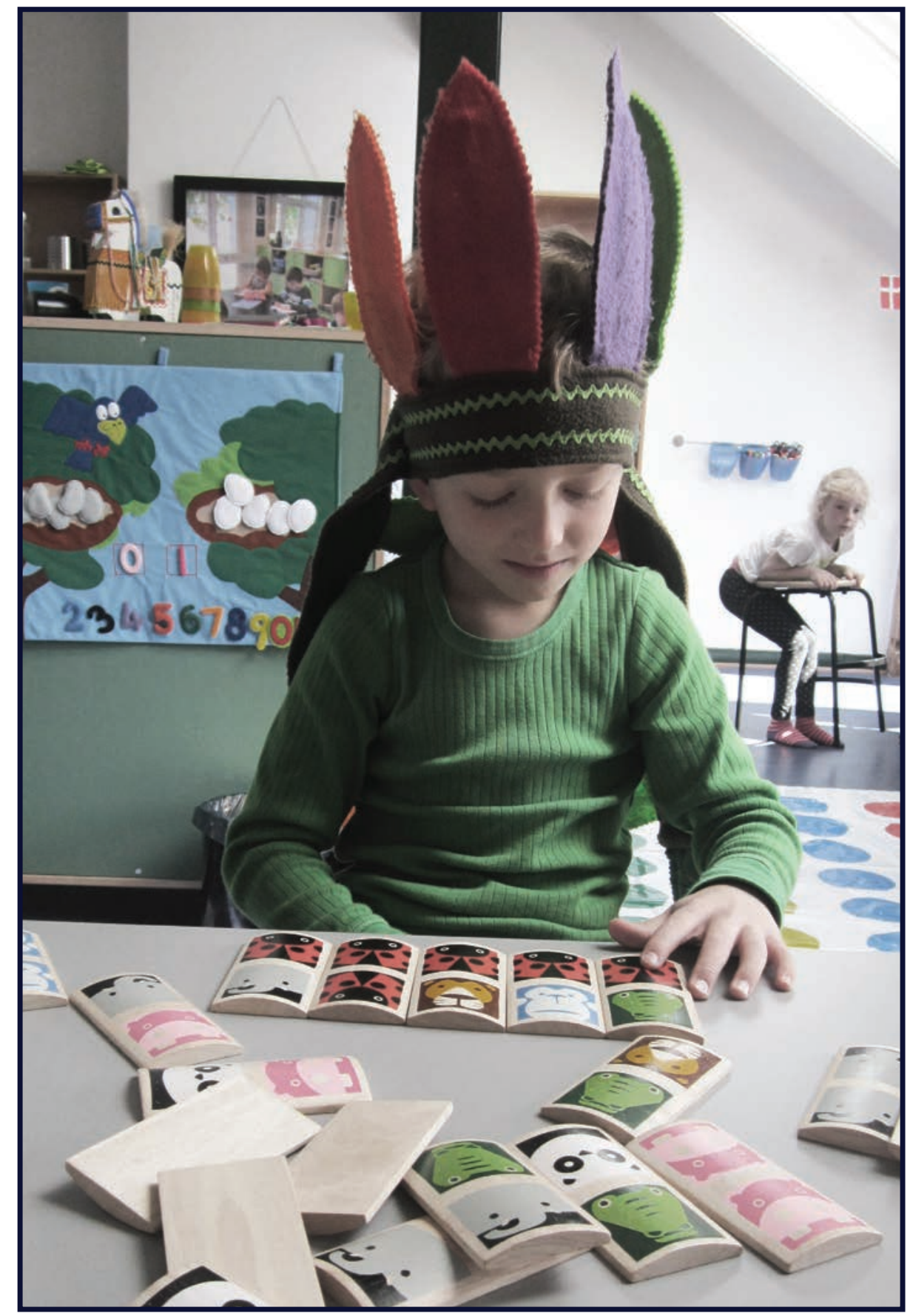

'Of course, we give them lots of recognition for their efforts, but there is a difference in saying something is good or bad or commending them for trying something new'.

Suzanne Crawfurd, teacher 


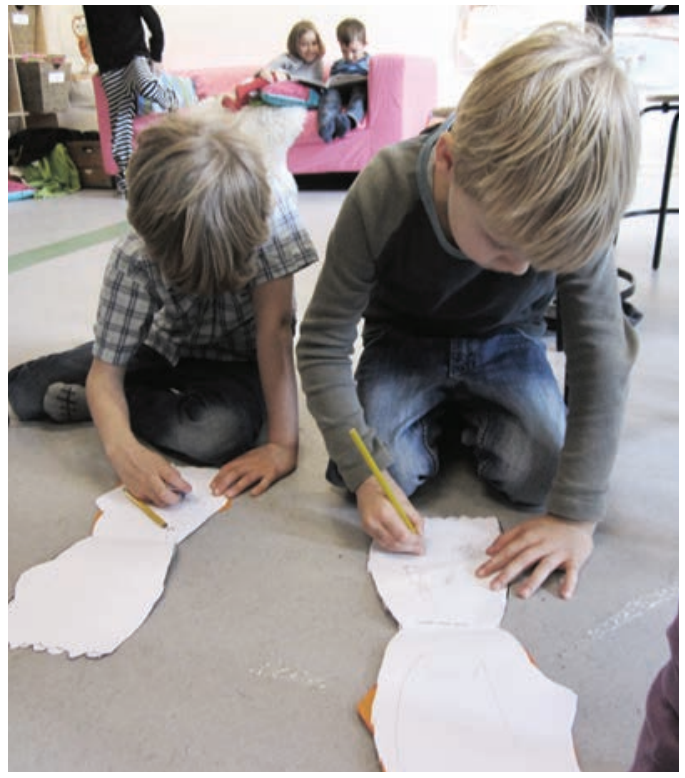

problem solving, because the teachers wish to get pupils accustomed to a work process in which the options are open and multiple. They would rather that pupils focus on the many ideas popping into their heads than arriving at a specific answer and receiving praise for that. 'It's about encouraging the thought process in a child without assessing whether what they have come up with is right or wrong. Of course, we give them lots of recognition for their efforts, but there is a difference in saying something is good or bad or commending them for trying something new', Suzanne Crawfurd explains.

Another example is that already in their first year, pupils become involved in the assessment of their own learning process. Together with an adult, they learn how to ask questions like 'how far have I got?' and 'what is my next step?' And to help them along, the pupils are given a chart where they can cross off for example being able to write seven letters of the alphabet or if they are able to add up numbers with more than one digit. Suzanne Crawfurd explains that right from the beginning, the children have to learn to relate to themselves. The task is giving them an sense of which direction they are heading in and how they can themselves influence where they go from there.

\section{WE BUILD ON THE MOVE}

It is not only the pupils who have to practice looking at themselves. For Suzanne Crawfurd and the rest of the staff at the school, trying new things, throwing some ideas out the window, and gathering alternative knowledge that they can then test in practice is all part and parcel of the job. The personnel group has decided on a very clear pedagogical goal, but they are not necessarily sure about how they are going to get there.

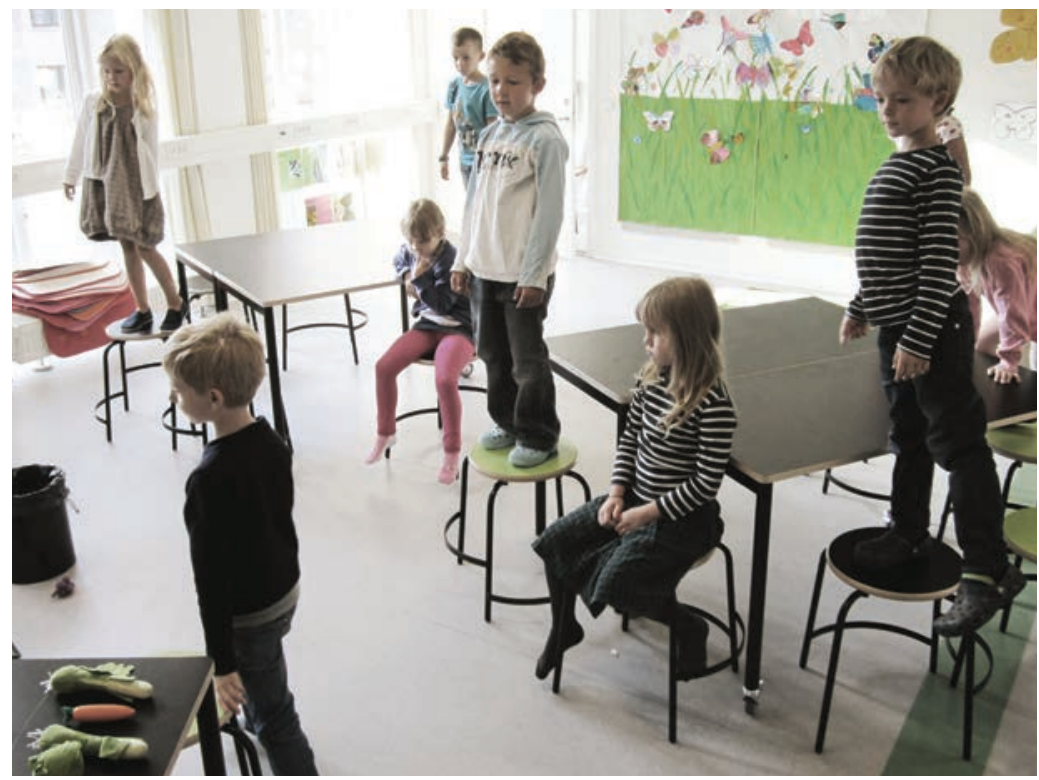

'The difference in my job here and at my previous school, is that here I spend a lot more time trying to locate new knowledge and new work tools. It's a process where we build a new school on the move, so to speak', Suzanne Crawfurd says before continuing, 'it's only when we pressurise ourselves to find new and better methods that I get the feeling that we are being innovative in the way we 'do' school - even if it is sometimes really difficult'.

At the same time, she also points to the fact that there is a limit to how many times you should throw things up in the air and start all over again within a short space of time. If the new school is to make any sense, it is also important to allow for work methods and pedagogical approaches to settle, grow and create results. 'We have to anchor somewhere. In a few years, some of the things we are doing now will probably have become more firmly rooted. Then we can start building on top of that again'.

\section{FREDERIKSBERG NY SKOLE}

* It opened its doors in August 2012 and currently has 242 pupils spread across three years, year 0 , year 1 and year 2 . For each year, the group of pupils expand with another year, and so in the course of ten years, the school will encompass years $0-9$.

* At Frederiksberg Ny Skole, there are no classes. Instead the pupils become part of communities called 'home-groups' where they may not be of the same age, but they share developmental needs, sleeping rhythm (chronotype), interests or something else.

* Teaching has been replaced by individual learning processes in which pupils spend much of their time together, while not necessarily learning the same tings at the same time.

* Teachers and pedagogues work side by side all day. This will often result in staffing equivalent to one adult for every twelve children. 


$$
\begin{aligned}
& \text { THEORY } \\
& \text { PUSHING } \\
& \text { PRACTICE }
\end{aligned}
$$

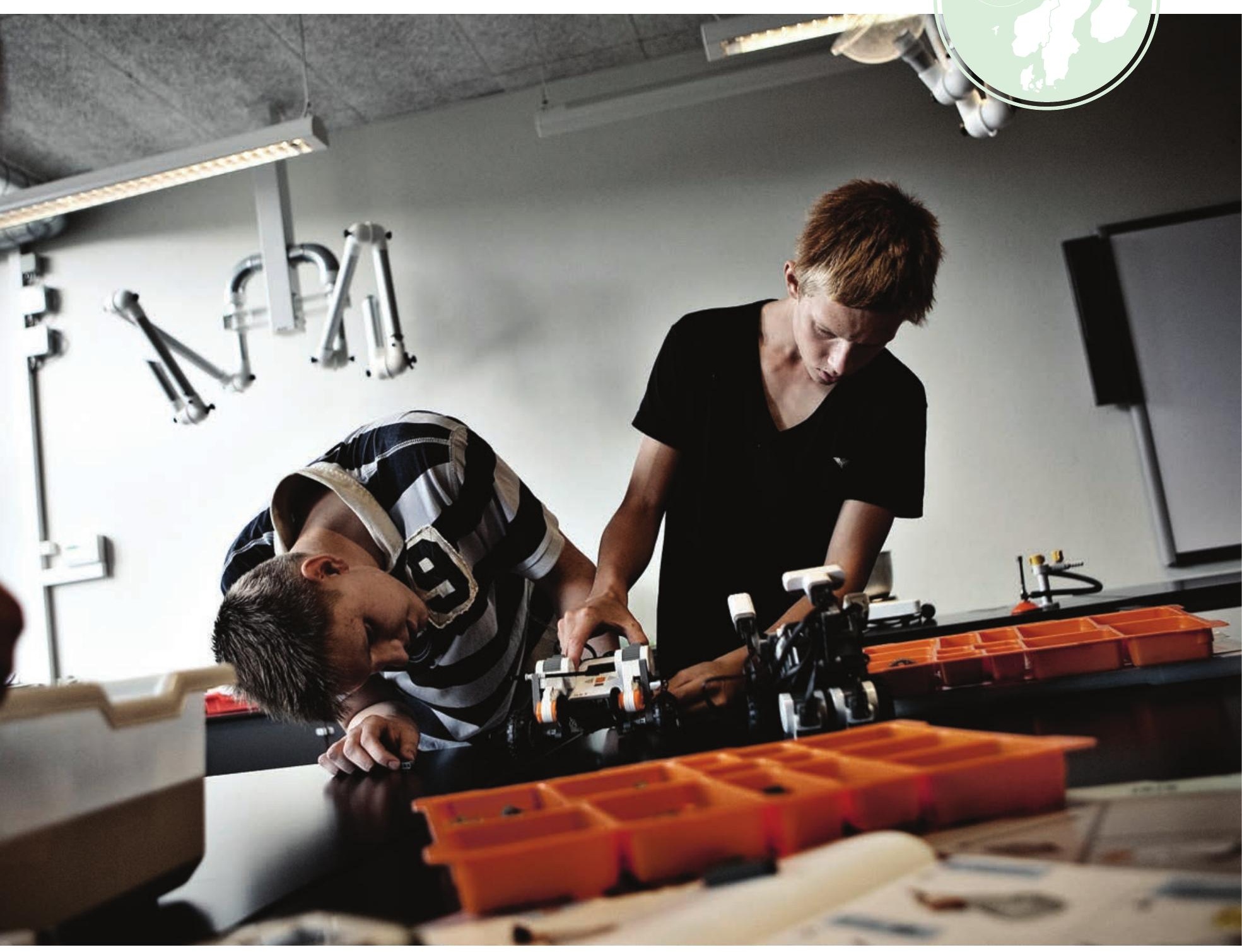


Well-established theory allows for a more hands-on teaching, which is why teachers at Løpsmark skole (school) in Bodø in the North of Norway currently attend university. At the school, there is no doubt that their focus on entrepreneurship education has resulted in higher marks.

$\mathrm{P}$ upils in the ninth year solder and assemble wires, paint pieces of cardboard, and then send their homebuilt electric car speeding across the floor in the physics lab. This assignment is an example of how Løpsmark skole works towards strengthening the pupils' competences in relation to entrepreneurship by making their teaching as hands-on as possible.

Only, at the school, they are not particularly fond of the word 'entrepreneurship'. 'Entrepreneurship is a loaded word, and we use it hesitantly. We are constantly searching for a better word, and we would rather use an expression such as 'pupil active learning", headmistress Vigdis Eriksen explains.

She also talks about how the school's focus on a more hands-on oriented teaching has resulted in pupils experiencing classes as much more varied. 'Previously, pupils and teachers could have highly differing takes on the teaching: while teachers believed themselves to be varying their teaching, pupils would often describe it as boring. Now, however, teachers are much better at communicating the different approaches they apply - and pupils find it easier to keep up'.

One of the teachers is Berit Myrvang who teaches English, maths and social sciences among other things. In order to strengthen the pupils' awareness of their own learning, she always ends her classes by talking about what they have learnt and how they have gone about it. 'I always discuss it with the pupils to make them more aware of the many different approaches open to a specific task which may also provide different results', she explains.

\section{THEY REALISED WHAT SCHOOL WAS ALL ABOUT}

In order to strengthen the development of the hands-on oriented teaching, Berit Myrvang along with other teachers from the seventh to ninth year, take part in a pilot project at Nordland University where they are taught pedagogical entrepreneurship in practice. As part of the course,

\section{'Previously, pupils and teachers could have highly differing takes on the teaching: while teachers believed themselves to be varying their teaching, pupils would often describe it as boring'.}

Vigdis Eriksen, headmistress

Berit Myrvang has worked on a concrete project at the school, in which pupils from the tenth year would engage in roleplaying, performing as the different countries in the UN Security Council. They used teaching material from the UN in Norway and the interdisciplinary subject taught them about everything from argumentation in Norwegian to statistics and GDP in maths.

'The way I approach teaching entrepreneurship, is very much about making it as hands-on as possible and attending university has allowed me to do just that. As a teacher, you are often very theoretically oriented, and a more hands-on approach takes some getting used to. However, attending the university course has increased my focus on practice and it has forced me to include a hands-on approach in my everyday teaching and not just in relation to larger projects', Berit Myrvang states.

In her experience, some of the pupils find the switch to a hands-on approach trying. 'There are some pupils who simply respond better to theory and when we started on the UN project, it was very difficult for them. For others it was absolutely fantastic. It was as if they suddenly realised what school was all about', she explains. Berit Myrvang also explains that over the last few years, the pupils' results in their oral exams have gone up and up. 'This year, our average was above five (the highest mark you can get is six, ed.) and I believe that that is due to the more hands-on approach which strengthens the pupil's oral capabilities, because they spend much more time rehearsing how to present subjects to one another than they did before. The written exams on the other hand, are very theoretical, and here marks have not gone up'.

\section{DROPPING OUT OF VOCATIONAL TRAINING STARTS IN PRIMARY AND SECONDARY SCHOOL}

Elisabeth Nielsen from the Senter for Pedagogisk Entreprenørskap (Centre of Pedagogical Entrepreneurship) at the University of Nordland is one of the forces behind the course in pedagogical entrepreneurship. She explains that the need for such a course springs from the development that schools have been through over the last many decades, in which focus was turned increasingly to theory. 'As a society, we right now face the challenge that many students drop out of vocational training. However, it is the result of a mental process that is initiated much earlier because we are not good enough at varying the teaching in primary and secondary schools. If we are to succeed in educating young people for all sorts of jobs, both academic and practical, we have to improve our teaching in every single classroom', she states.

According to Elisabeth Nielsen, these new teaching methods can help make visible the individual pupil's competences and thus individualising the teaching will better prepare the pupils for different types of further education.

\section{THE UN}

SECURITY

\section{COUNCIL IN CLASS}

The teaching material Berit Myrvang used in relation to her UN Security Council project can be found here: www.fn.no/skole (in Norwegian). 

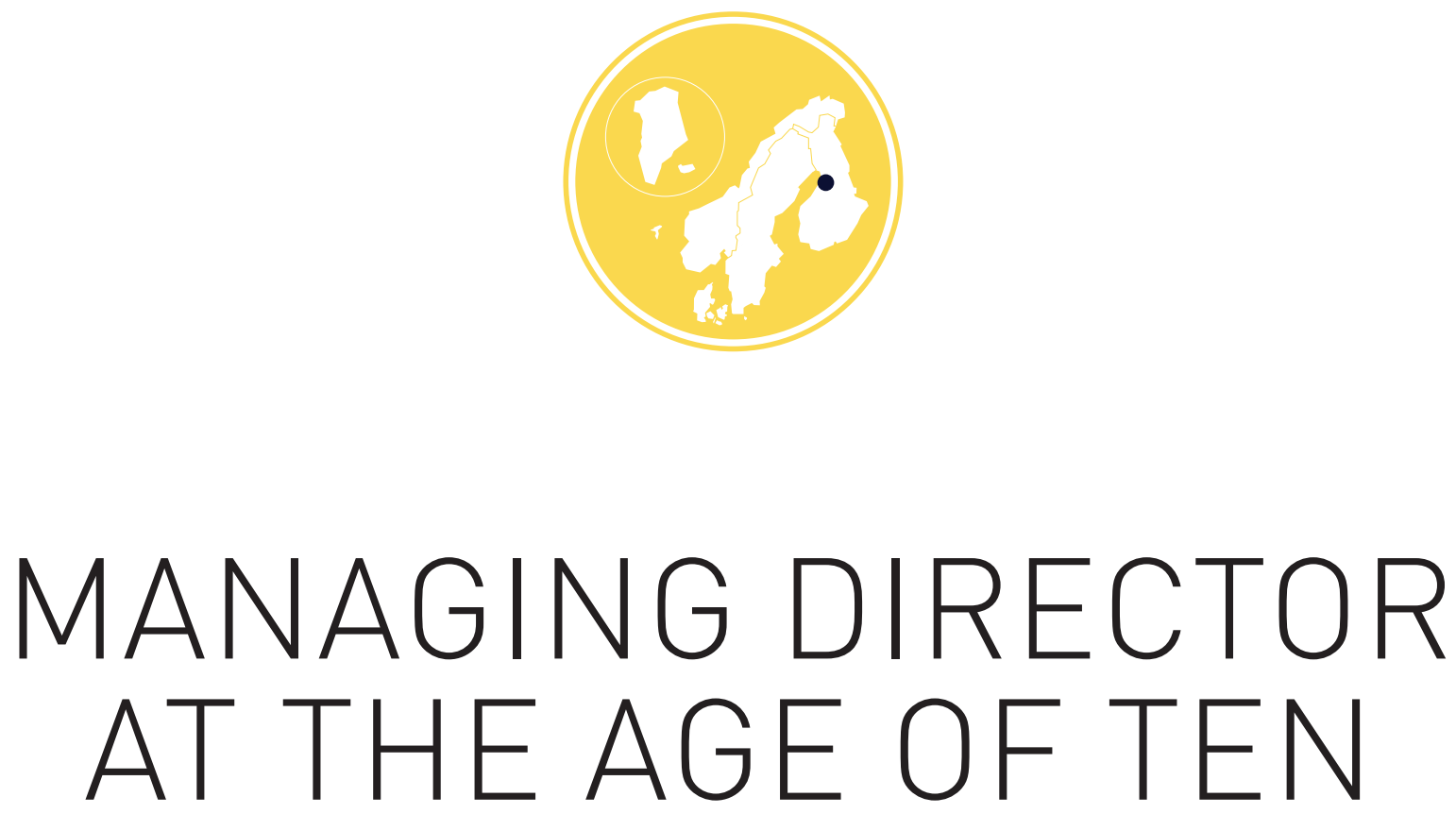

\begin{abstract}
Even the youngest pupils can get a lot out of collaborating with the business world. At least this was the experience at Patamäki School in Oulu, Findland, where pupils in the first to fourth year worked as entrepreneurs for six hours a week over the course of two months.
\end{abstract}

$\mathrm{W}$ hen the smaller classes at Patamäki School tried their hand at being entrepreneurs in the school year 2012/2013, they had to present both business and marketing plans. In the project called Kodu, the pupils were divided into groups and tasked with developing a computer game on which they would then build a computer gaming business. For example, one group developed a game where you learn English by moving a figurine over English words to get the Finnish translation.

The pupils however, were not left to their own devices. Mentors from the business community would assist them by, among other things, holding Skype-meetings with the pupils. Their mentors spanned widely from employees in the gaming industry to consultants who specialised in collaborations with small enterprises. Their task was keeping the project as real as possible, while also making the pupils reflect on the choices they made along the way.

'As an example, one mentor told a pupil: 'you have estimated a profit of EUR 100,000, but your game costs no more than EUR 6 . Do you really expect to sell that many games?' The pupil then explained that his computer game was so advanced that he couldn't even complete it himself yet, and so he felt confident that they would be able to reach their goal, to which the mentor replied that if the pupil was convinced, then so was he', Jukka Miettunen, headmaster at Patamäki School, recounts.

\section{A NEW WORD - A NEW LANGUAGE}

In advance of the project, the teachers had created one big company, after which the pupils were divided into eight smaller companies. Teachers of the third and fourth year groups decided who would be managing directors and then the pupils themselves delegated who would be financial director, marketing director etc. of the smaller businesses.

The younger pupils had to decide for themselves who would be managing director, however, not every group found it easy to persuade someone to take on the responsibility of leadership. Paula Vorne who taught the first year group at the time of the project, explains how she prepared her pupils for the task

\section{KODU}

The first project at Patamäki School was called Kodu. The inspiration for this name came from the Microsoft tool called Kodu, which is a platform where children and adults try their hand at designing their own computer game. You can read more about Kodu and download your own version here: www.kodugamelab.com 


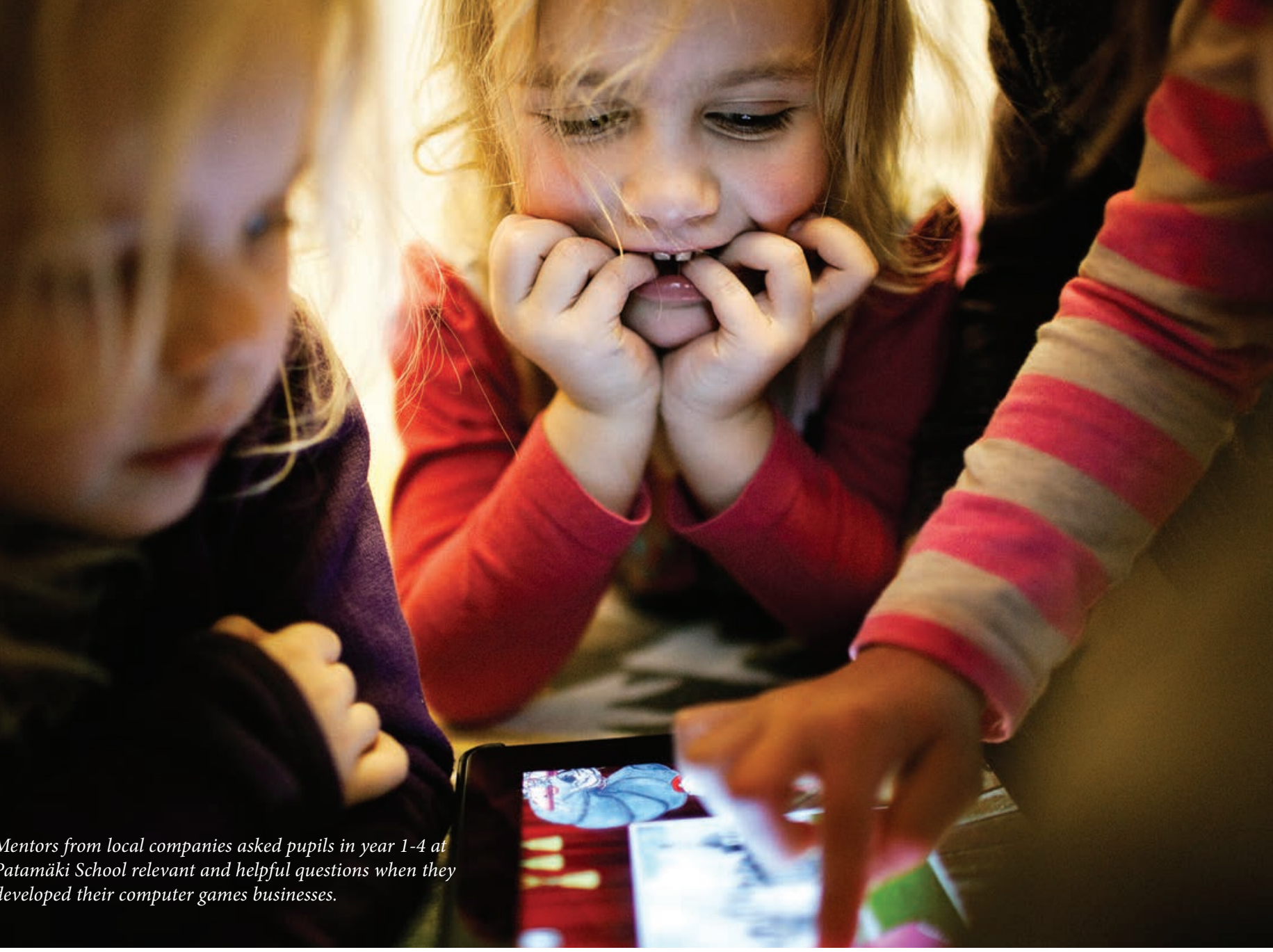

Mentors from local companies asked pupils in year 1-4 at Patamäki School relevant and helpful questions when they developed their computer games businesses.

through group work - even before the project started. "I really didn't know what to expect. The pupils were so young, and I wondered if they would understand what their task was, and if they would be able to do so much work in groups. However, once we got started, I found that they took surprisingly well to having such firmly defined roles', she says.

For the teacher, having to deal with business and marketing plans as well as budgets was also like engaging in a completely new world. 'Fortunately, I have a business background, while many of the other teachers would get help from their spouses who work in the private industry. It helps us better speak the business lingo', Jukka Miettunen explains.

\section{SNOW HOW - A NEW PROJECT IS UNDER WAY}

In a short while, when the school embarks on yet another such project under the title of 'Snow How', all pupils in the first to sixth year groups will have to participate. They will be tasked with creating businesses with the common denominator that they develop and deliver services related to snow. There will be local businesses, institutions and private persons who may wish to pay for someone to remove snow from their driveway, or buy a ticket to a theatre performance about snow.

In order to encourage pupils to take leadership, the teachers have decided to add another layer to the project. This time
'I really didn't know what to expect. The pupils were so young, and I wondered if they would understand what their task was, and if they would be able to do so much work in groups. However, once we got started, I found that they took surprisingly well to having such firmly defined roles'.

Paula Vorne, teacher

around, pupils who are interested will have to write an application for the position of managing director - and the successful applicants will then have to employ their fellow pupils in the remaining positions in their companies. 'We want to give those pupils who have a talent and the wish to be leaders an opportunity to strengthen that competence even more so than we did in the first project', Paula Vorne explains. 

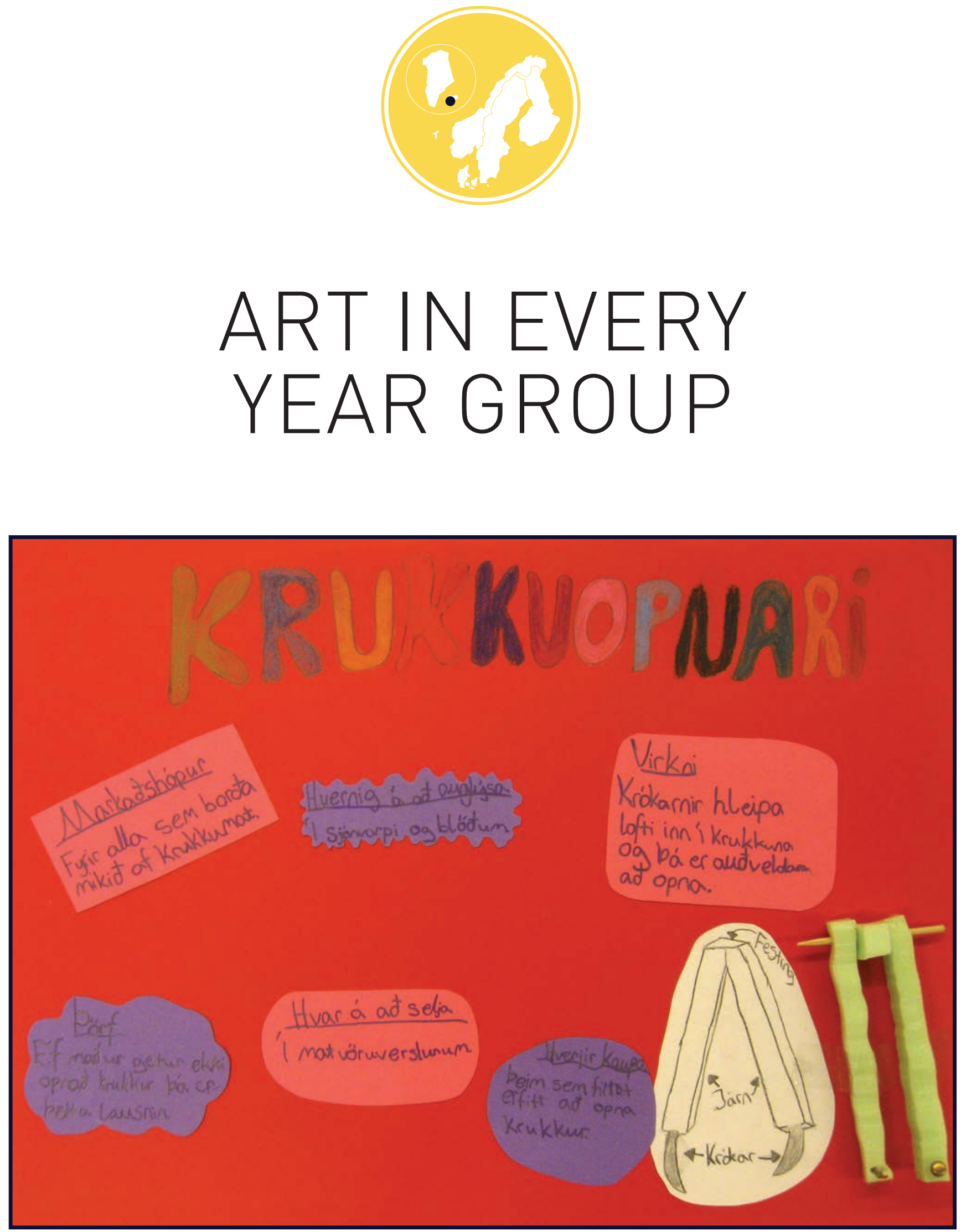

Wall sheet explaining the thinking behind the invention of a new tin-opener. 
$\mathrm{A}$ t Ingunnarskóli in Reykjavík an artistic approach to teaching constitute the common thread across year groups. In the fourth to seventh year, teaching innovation is a recurring feature as pupils learn how to identify a need in their local environment and then work on developing a product that can fulfil that need.

Two double art lessons per week. This is how much time art is allocated in year groups 1-7 at Ingunnarskóli. 'In addition to the regular hours of teaching we are constantly trying to integrate an artistic approach in the other subjects as well', Guðlaug Erla Gunnarsdóttir, the school's headmistress, explains.

In Iceland, they have a national framework for schools, but the individual schools decide their own curriculum, which allows them to prioritise certain subjects. Nonetheless, Ingunnarskóli's strongly artistic focus is something out of the ordinary, Michael Dal, researcher of pedagogical entrepreneurship at Den Pædagogiske Universitetsskole (the Faculty of Education Studies) at the University of Iceland, says. 'In general, Icelandic schools work extensively with art, but at Ingunnarskóli they do it very systematically. The school distinguishes itself by really working to activate the pupils - and by being very successful at it', he adds.

\section{BUILT WITHOUT CLASSROOMS}

Ingunnarskóli opened in 2005. The school building contains large and open teaching areas. It is designed with interdisciplinary teaching and creativity in mind. 'On a practical level, the school is organised in such a way that the pupils are divided into groups of 60-90 children. They work in open spaces in the constant presence of approximately four teachers. Furthermore, the teachers of artistic subjects are also on hand most of the time', Guðlaug Erla Gunnarsdóttir explains.

Art classes at Ingunnarskóli include needlework, visual art, design, digital art and music and often, disciplines will be combined in a project to enhance the pupils' creative skills in relation to both innovation and communication. 'By working creatively with innovation and communication in this fashion, you strengthen the pupils' understanding of their own learning process. You could say that you train their innovative skills by having them not just reproduce but in fact co-create knowledge', Michael Dal says.

\section{INNOVATION CLASSES}

To further enhance the pupils' innovative skills, they receive targeted innovation teaching in years four to seven, one double lesson each week, equivalent to approximately one full year. They will learn to identify needs in their local community and then work towards developing products that can fulfil those needs. Or they may come up with new ways of utilizing existing products.

By way of example, some pupils have worked on developing a tool that would make it easier for elderly people to open tin lids. Others have created a bag that can turn into a small seat. Thorgerdur Hlodversdottir teaches innovation in years four to five. She explains how pupils utilize the skills they have learned in art classes: 'For example, when they have to draw and build models with different materials, art classes will already have familiarized them with thinking about the aesthetic presentation of an idea'.

Innovation classes also have an effect on the other subjects taught, Thorgerdur Hlodversdottir elaborates, 'Teachers of other

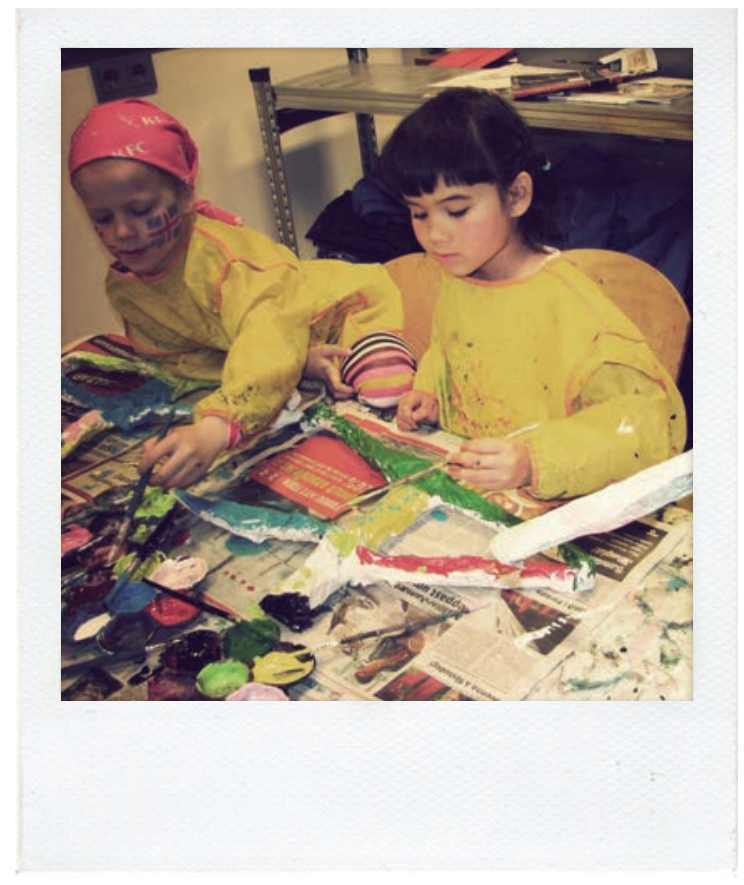

subjects tell how pupils become more creative and open to trying new things once they've been through a process with innovation teaching. They also gain in self-confidence and are generally more engaged in the teaching'.

\section{'Teachers of other subjects tell how pupils become more creative and open to trying new things once they've been through a process with innovation teaching. They also gain in self-confidence and are generally more engaged in the teaching'.}

Thorgerdur Hlodversdottir, teacher

\section{DOING WELL IN NATIONAL TESTS}

According to Michael Dal, the focus on creativity and innovation at Ingunnarskóli is also visible in the school's results in the national tests. The school does somewhat better than comparable schools. 'The remarkable thing is that most of the pupils here do well. Hardly any of them figure right at the bottom, which I consider a sign that the school has been highly successful in differentiating their teaching without compromising subject knowledge. There are many indicators pointing to the fact that the work methods employed at Ingunnarskóli means fewer pupils left behind than in traditional teaching', he says. 


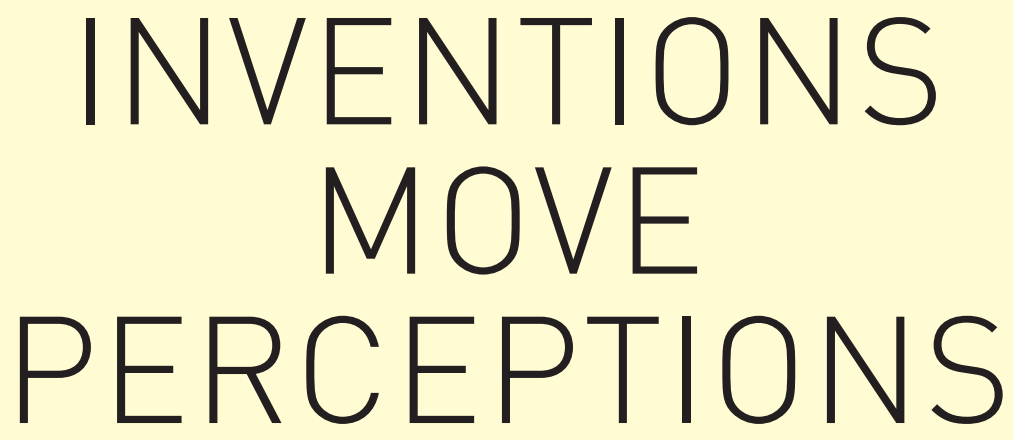

For more than 30 years, Finn upp, the competition for inventors in Sweden, has tried to solve a societal problem that might prove unsolvable. But then again, they are very successful in changing the way pupils think about natural sciences.
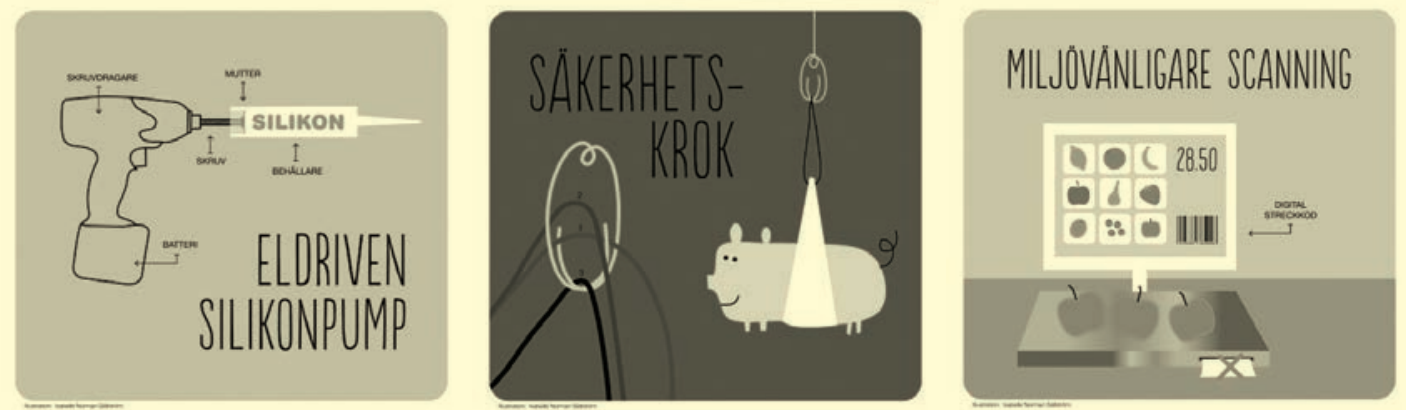


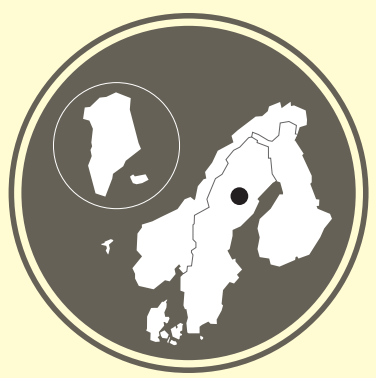

$\mathrm{S}$ weden in the year 1979: the number of young people who choose to further educate themselves in technical or natural scientific subjects is dwindling rapidly. In fact, it is such a problem that the magazine Ny Tidning (New Newspaper), Ingenjørsamfundet (The Engineering Society) and Svenska Uppfinnareföreningen (Association of Swedish Inventors) decide that they have to do something about it. And thus the competition for inventors, Finn upp, is born.

Since then, ten-thousands of children aged 12-15 have participated in the competition with inventions that solve problems they come across in their everyday lives - at school or in the local community at large. In 2012, prizes were awarded for a diversity of inventions, including a safety hook for animal transportation, a sustainable soap dispenser and hiking trousers that can be blown up to avoid getting your bottom wet when sitting on a stub of wood.

If you ask project manager of Finn upp, Carl Elfgren, whether they have managed to solve the problem of not enough young people taking an interest in the natural sciences, the answer is a resounding, 'No. We still need engineers and others within the fields of technique and natural sciences. But on the other hand, demand is also growing in tune with the expanding society. So it's not really surprising'.

\section{MUCH MORE THAN A COMPETITION}

Carf Elfgren also points to the fact that in time and as a consequence of the general educational development, Finn upp has taken on more roles than originally intended. 'There is an ever increasing demand for technique and natural science teachers to incorporate creativity in their teaching while at the same time they also have to enhance the pupils' independence. And as it turned out, Finn upp fits right into that mould', he says.
Victoria Hvirfvel, a natural science teacher at Finnbacksskolan in Lycksele, is also familiar with those demands. She has taught several courses where pupils have worked on inventions that have subsequently been registered for the Finn upp competition - though so far, they have not won any prizes. To her, more than anything, Finn upp is a welcome opportunity for her pupils to realize what she actually teaches.

'Many children and young people have a very set idea of what technical and natural science subjects involve. You can change this perception by allowing them to locate problems and invent solutions on their own. And then suddenly they realize that there are a lot of technical skills involved in developing a running shoe that works properly, and that a wheelchair does not operate on its own'.

In addition to developing and facilitating the competition itself, the people behind Finn upp have collected a lot of material that teachers can use in their teaching up until the time when pupils have to admit their inventions for assessment. Teachers can use this material, aptly called Uppindarresan (An Inventive Journey), to set up longer processes where pupils learn how to come up with and develop ideas, create designs, and not least consider how to realise their ideas.

\section{NEW PERCEPTIONS OF NATURE AND TECHNIQUE}

For Carl Elfgren, adjusting to the fact that the new demands placed on teachers also means new demands for Finn upp has been very important. Over time, teachers have had a lot more offers to choose from, which is why Finn upp is engaged in a constant battle for the teachers' favour. The people behind the competition try to make it as easily accessible and as up-todate as possible because 'If we don't, they'll go somewhere else', Carl Elfgren says.

\section{'Many children and youths have a very set idea of what technical and natural science subjects involve. You can change this perception by allowing them to locate problems and invent solutions on their own'.}

Victoria Hvirfvel, teacher

This is also the reason why Finn upp is experiencing growing pains this year. From 2014 onwards, the competition will no longer take place every three years but rather every year. At the same time, the number of local and regional competitions will also increase, which will enable more people to participate.

So regardless of the fact that Finn upp's attempts at curbing the lack of natural science students may at times look much like Sisyphus' daily trip up the hill, Carl Elfgren still believes that Finn upp makes as much sense now as it did back in 1979. 'It may well be that we cannot solve the general problem in society. But then again, our assessments show that 65 per cent of the pupils who have been part of Finn upp say that they have a more positive understanding of technical and natural science subjects than they had before. And I would venture that that is an improvement that counts', he concludes.

\section{FINN UPP}

At Finn upp's webpage you can learn more about the competition and the materials available in Uppfinnarresan at: www.finnupp.se/uppfinnarresan 

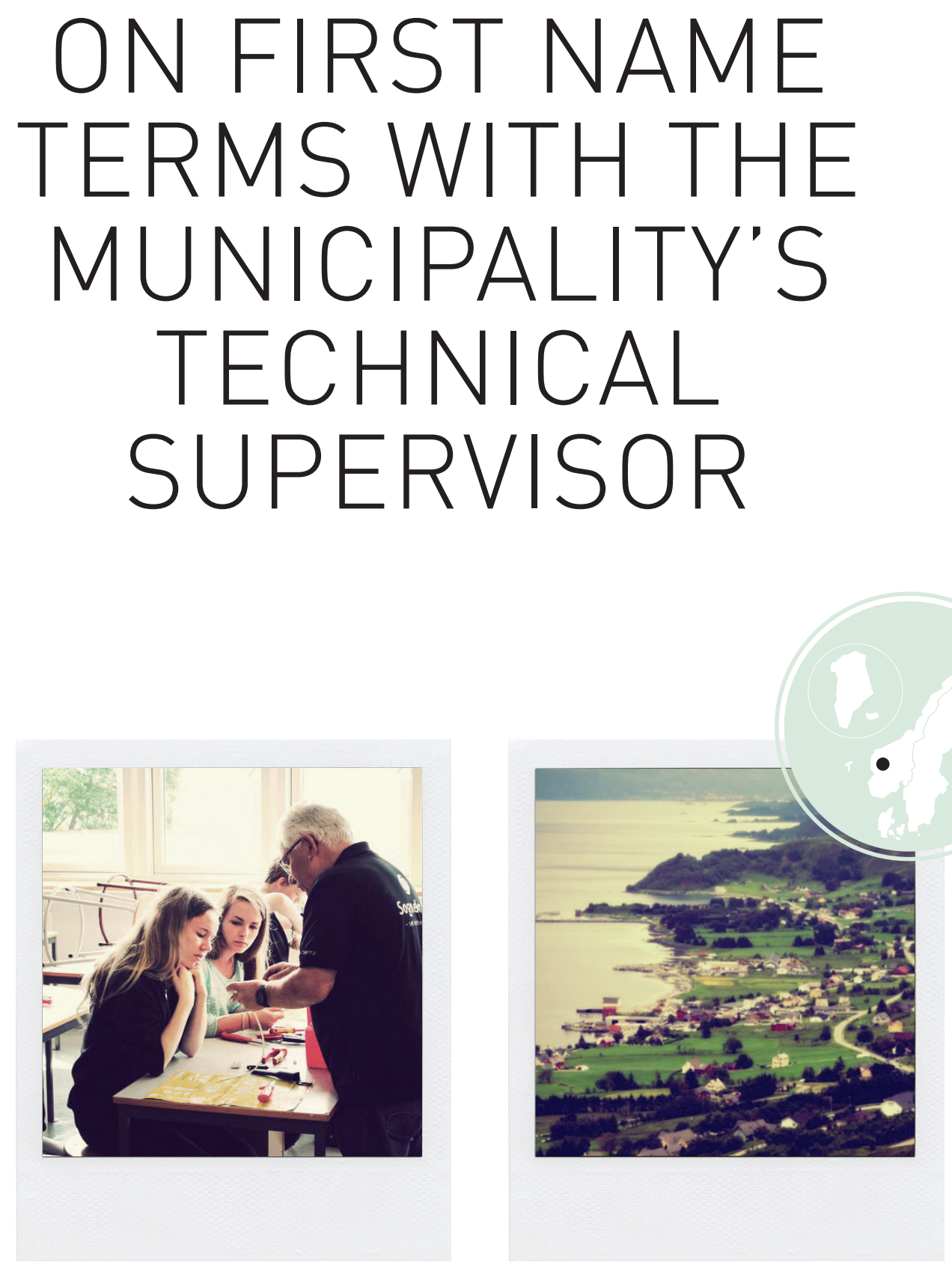

For years, they have worked with partnership deals at Leikanger ungdomsskule lyouth schooll in Norway. The deals are made between the school and local businesses as well as local and regional institutions. The pupils must learn that the school is not an isolated unit but an important part of the local community. As they themselves are. 
$\mathrm{O}$ ffhand, the title Municipal Technical Supervisor may be one you associate with a person hidden away behind walls of bureaucracy and stacks of paper - and the person may even be wearing a grey suit if your picture happens to be in colour. In the municipality of Leikanger in Norway, nothing could be further from the truth. On the contrary, it is not uncommon for the technical supervisor to walk around town with pupils' from Leikanger ungdomsskule's eighth year group in tow. He will explain why the church and the nursery are located in their exact spots and he will provide general information about the municipality.

And he is not just doing it, because he may - consider it good fun. He is also doing it because he has to. Because Leikanger ungdomsskule has entered into a so-called partnership deal with Leikanger Municipality, Sogn and Fjordane Fylke (county) and numerous other businesses within the local community. The partnership deals constitute part of the school's plan for entrepreneurship education and it includes all pupils at the school (seventh to tenth year). The plan is constructed so that pupils will start by building up local knowledge in their eighth year through a project called 'bygdi vår' (Our Village). This project involves not only Leikanger Municipality but also Sparebanken Sogn and Fjordane (a bank) as well as the national road authority (Statens Vegvesen). The plan then moves on to 'pupil-business' in year nine and concludes with a business and educational theme in the tenth year, which includes a fieldtrip abroad. The idea behind it all is to have the competences acquired in one year build on the competence of the previous year - including the ability to create local networks and knowing how to carry on once school is finished.

\section{SCHOOLS ARE A RESOURCE IN SOCIETY - NOT THE OTHER WAY AROUND}

Leikanger ungdomsskule began working systematically with entrepreneurship education in 2000. As was the case in many other smaller communities, they wrestled with the problem of young people leaving town once they had finished secondary school, never to return. So the school had to contemplate what it could do to keep young people from moving away. 'We had to take action, knowing that we as a school are also responsible for the local community. And so we sat down and found out what we could do to make people want to move back to the area once they'd completed further education in another, larger town' says Reidun Sterri Fjell, a teacher of maths, natural sciences and arts and crafts. He is as also a careers adviser at the school.

\section{'We had to take action,} knowing that we as a school are also responsible for the local community. And so we sat down and found out what we could do to make people want to move back to the area once they'd completed further education in another, larger town'.

\section{Reidun Sterri Fjell, teacher}

An important part of the solution was building up the teaching of entrepreneurship through partnership deals within the local community. The thesis behind the deals is that the more local knowledge the pupils obtain through their schooling, the greater their sense of belonging within the local community will be in the future. The technical supervisor's walks with the pupils are thus part of a greater plan to have pupils experience the local community as theirs. They get to experience that people working for the municipality are more than grey suits behind stacks of paper and that they actually matter in terms of what the town looks like and how it develops - and how they influence the pupils' own lives. 'Among other things, we explain why the bridge they cross each day on their way to school is located in that precise spot', Reidun Sterri Fjell states.

\section{INCLUDING THE CURRICULUM}

After test-driving the partnership deals for a few years, it is more or less smooth sailing these days. 'The deals are no longer dependent on specific people; they are signed by the headmaster and associated teachers and they last for three years. Everyone affiliated with the school knows about the deals, and both the school and its partners keep taps on whether or not the various activities are carried through', Reidun Sterri Fjell elaborates.

The school did encounter some birthing problems though. 'Getting teachers to comply with the partnership deals proved somewhat of a challenge, and to keep taps on whether or not the deals were adhered to, the headmaster scheduled a weekly meeting where the partnership deals were discussed with the teachers involved', Reidun Sterri Fjell explains as she emphasises that working with partnership deals means you have to be realistic about what can actually be accomplished. 'In the beginning, it was just too much. We had to make mistakes', she says before elaborating on how utilizing the curriculum actually proved helpful. 'The visits had to have some sort of subject connection to the curriculum. Visits to businesses should not be an appendix but a tool that can be used to reach and concretise set learning goals'.

Both partners and pupils have responded very positively to the deals. The pupils are more engaged than they were before because they experience new sides of their community and they are introduced to new possible educations, according to Reidun Sterri Fjell. About the partners, she has this to say, 'It was as if they had been waiting for this collaboration to happen. It started in 2000 and it is still successful today'.

\section{PARTNERSHIP}

\section{DEALS}

The partnership deals at Leikanger ungdomsskule set a precedent for other schools in Sogn and Fjordane Fylke. In 2009, Sogn and Fjordane was the county in Norway with the most partnership deals between schools and Näringslivets Hovedorganisation (The Confederation of Norwegian Enterprise). 
WHEN I GROW UP

- A NoRdic MAgAZINE ABOUT ENTREPRENEURSHIP EDUCATION IN PRIMARY AND SECONDARY SCHOOLS

ISBN 978-92-893-3798-4

http://dx.doi.org/10.6027/ANP2014-753

ANP 2014:753

(C) Nordic Council of Ministers and Monday Morning 2014

\section{Project management}

Monday Morning, www.mm.dk

Iben Berg Hougaard, project supervisor and manager

The Nordic Council of Ministers, www.norden.org/en

Morten Friis Møller, senior advisor

\section{DESIGN}

Anne Sofie Bendtson, Monday Morning

\section{Translation}

IP Words v/Iben Philipsen

\section{Рнотол}

As far as it has been possible, photographs have been obtained from the schools and projects mentioned in the magazine. In addition there are photographs by:

Ditte Valente, front page and p. 39

Astrid Dalum, p. 10

Marius Nyheim, p. 26

Simon Fals, p. 28

Joachim Adrian, p. 36

Print: Rosendahls-Schultz Grafisk

Copies: 200

Typeface: Minion Pro

Paper: Munken Polar

Printed in Denmark

This publication has been published with financial support by the Nordic Council of Ministers. However, the contents of this publication do not necessarily reflect the views, policies or recommendations of the Nordic Council of Ministers.

www.norden.org/en/publications

\section{Nordic co-operation}

Nordic co-operation is one of the world's most extensive forms of regional collaboration, involving Denmark, Finland, Iceland, Norway, Sweden, and the Faroe Islands, Greenland, and Åland.

Nordic co-operation has firm traditions in politics, the economy, and culture. It plays an important role in European and international collaboration, and aims at creating a strong Nordic community in a strong Europe.

Nordic co-operation seeks to safeguard Nordic and regional interests and principles in the global community. Common Nordic values help the region solidify its position as one of the world's most innovative and competitive.

\section{Nordic Council of Ministers}

Ved Stranden 18

DK-1061 Copenhagen $\mathrm{K}$

Phone (+45) 33960200

www.norden.org 





\section{norden}

Nordic Council of Ministers

Ved Stranden 18

DK-1061 København K

www.norden.org 